\title{
Making demand side response happen: $A$ review of barriers in commercial and public organisations
}

Article

Accepted Version

Creative Commons: Attribution-Noncommercial-No Derivative Works 4.0

Cardoso Araya, C., Torriti, J. and Lorincz, M. J. (2020) Making demand side response happen: A review of barriers in commercial and public organisations. Energy Research \& Social Science, 64. 101443. ISSN 2214-6296 doi: https://doi.org/10.1016/j.erss.2020.101443 Available at https://centaur.reading.ac.uk/88976/

It is advisable to refer to the publisher's version if you intend to cite from the work. See Guidance on citing.

To link to this article DOI: http://dx.doi.org/10.1016/j.erss.2020.101443

Publisher: Elsevier

All outputs in CentAUR are protected by Intellectual Property Rights law, including copyright law. Copyright and IPR is retained by the creators or other copyright holders. Terms and conditions for use of this material are defined in the End User Agreement.

www.reading.ac.uk/centaur 
Central Archive at the University of Reading

Reading's research outputs online 


\title{
Making demand side response happen: a review of barriers in the commercial and public sector
}

\author{
Catarina Araya Cardoso ${ }^{\mathrm{a}^{*}}$, Jacopo Torriti $^{\mathrm{b}}$, Mate Lorincz ${ }^{\mathrm{c}}$ \\ ${ }^{a}$ Westminster Business School, University of Westminster, 35 Marylebone Rd, London NW1 \\ 5LS, United Kingdom \\ b, c School of Built Environment, University of Reading, Whiteknights, Reading, RG6 6AF, \\ UK \\ * Corresponding author
}

E-mail address: catarinaacardoso@icloud.com

\section{Keywords:}

Demand Response

Demand Side Response (DSR)

Flexibility

Non-domestic sector

Service sector

\section{ABSTRACT}

The decarbonisation of electricity systems and the associated increase in variable generation sources requires an increase in power system flexibility. Demand side response (DSR) is widely viewed as a cost-effective source of flexibility, with considerable market potential. To date, the main DSR providers have been energy intensive firms. However, the expectation is that non-energy intensive consumers such as commercial firms and public sector organisations, will also help to provide system flexibility. Despite its DSR potential, the commercial and public sector has received little attention in the literature. This paper helps address this gap by identifying and exploring barriers to the participation of large commercial firms and public sector organisations in DSR through a review of the academic and grey literature on DSR. Drawing on the literature on barriers to energy efficiency, we use concepts from orthodox and behavioural economics, organisational studies and social practice theory to frame our analysis. The article argues that barriers to participation in DSR exist at the level of the organisation and not only the site. For large commercial firms and public sector organisations, the combination of having small individual electricity loads and complex internal decision-making processes can hinder their uptake of DSR. The hidden costs of participation, issues of bounded rationality and what the energy is used for within different organisations also limit the firms' ability to participate in DSR. 


\section{Introduction}

Addressing climate change requires the decarbonisation of the power sector and, as a result, international bodies and governments are encouraging investment in renewable energy [1,2]. In the future, power systems are expected to have higher shares of variable power from sources such as wind and solar, requiring additional flexibility sources on the demand side to maintain system reliability. Demand Side Response (DSR) is considered a cost-effective flexibility source with relatively limited technological impediments [3,4]. Its deployment can contribute to price stability in power markets, optimise the utilisation of existing infrastructure and reduce the need for future investments in network and peak generation capacity [5]

DSR refers to a wide range of actions taken by electricity users in response to specific conditions within the electricity system [6]. Electricity users may be required to temporarily reduce, increase or shift their electricity consumption; this can be achieved by changing actual consumption, or by using on-site generation and storage instead of consuming power from the grid. To date, the uptake of DSR has been relatively limited, although its potential is considerable. The International Energy Agency estimates that DSR could provide a worldwide reduction of $16 \%$ in peak demand $[7,8]$. In Europe, there are currently only $21 \mathrm{GW}$ of DSR capacity (4.4\% of peak load), but the theoretical potential is $110 \mathrm{GW}$; by 2030 this potential could be as high $130 \mathrm{GW}$ (22\% of peak load) [9]. There is a considerable body of research examining the barriers to DSR deployment from a system perspective, such as the difficulties of valuing and integrating this resource into electricity markets [5,10-13]. Considerably less has been written about DSR from the perspective of electricity end-users, whose cooperation and participation is essential for the deployment of DSR. Most DSR is currently provided by energy intensive firms, but for the potential of DSR to be achieved, non-energy intensive sectors also need to participate. However, there remain many gaps in our understanding of the factors that influence electricity consumers' ability and willingness to provide flexibility services to the system [14]. A category of electricity consumers which has received particularly little attention in the literature is the commercial and public sector. Some studies estimate that the DSR potential of this sector is similar to that of industry $[15,16]$, but their participation in DSR programmes is generally low $[15,17,18]$. Large commercial firms and public sector organisations are often considered to be well positioned to provide flexibility services to the system, as they tend to be high electricity consumers and have the necessary enabling technology. However, even amongst large consumers, rates of engagement in this sector are low [19].

This article explores barriers to DSR amongst large commercial firms and public sector organisations through a review of the academic and grey literature on the subject. As a theoretical framework we use concepts from four different theoretical perspectives: orthodox economics, behavioural economics (BE), organisational theories and social practice theory. This framework was inspired by the literature on barriers to energy efficiency (EE), which has also been sometimes used in other studies of DSR barriers [14,20,21].

There is a large body of literature that examines energy users' uptake of EE measures. In the late 1970s, the high costs of producing electricity meant that several countries started encouraging EE initiatives to reduce energy demand. EE is now also a key climate change policy, as lowering energy demand helps reduce carbon emissions. Whilst little has been written on DSR from the perspective of energy users, a central area of research in the EE 
literature is the 'energy-efficiency gap', which examines the reasons for organisations' underinvestment in apparently profitable EE initiatives [22-24].

The literature on the EE gap can be useful to examine barriers to DSR participation for three reasons. First, studies on the EE gap tend to use a multi-disciplinary approach in their analysis, which can enable the identification of a more comprehensive set of barriers as the problems under examination are considered from different perspectives. For example, while some theories will focus on the barriers that originate at the level of the individual others will emphasise the role of organisational factors in restricting the uptake of EE projects. Second, from the perspective of firms and public sector organisations, there are several similarities between EE and DSR. Both DSR and EE are energy management innovations [21]. Both are relatively optional. The benefits of increased energy efficiency and more demand side flexibility in the system are generally agreed, and both measures are often advocated as being cost-effective for businesses. However, a gap remains between estimates of EE and DSR potentials and businesses' uptake of these initiatives. Within firms, both DSR and EE are the responsibility of energy departments but require support from other parties of the organisation and are both likely to be evaluated by the same criteria $[15,21,25]$. Third, the EE literature includes barriers that focus on the features of the organisation [26,27] rather than solely on the characteristics of the innovation itself. These concepts are useful in identifying obstacles to the participation of businesses in DSR that are influenced by factors which exist independently of the demand side management innovation.

The EE literature can thus provide inspiration for useful theoretical concepts to identify and explore barriers that, from the perspective of energy consumers, hinder their participation in DSR. However, EE and DSR are also clearly different. DSR is a relatively new demand innovation, which is considerably complex for the non-energy specialist [28,29]. EE measures involve permanent or regular changes to consumption, whereas DSR requires changes to consumption patterns that are temporary, and which can consist of relatively short periods (minutes or seconds) [15,30]. The value of these changes is highly dependent on developments outside of the firm and this reflects one of the fundamental differences between EE and DSR: engaging in demand side response is characterised by a dynamic and constant interaction with markets $[17,20,21]$. This interaction with markets leads to further differences between EE and DSR. First, to participate in DSR firms need to have a metering, control and communication infrastructure which allows for two-way communication and the transmission of significant amounts of data [15,31,32]. By contrast, technical requirements for improving the EE performance of a business can be very low, especially during the first stages or if the focus is on behaviour change [33]. Second, financial returns are hard to predict as they depend on the DSR options the company can participate in, and the return rates on these products are not constant $[14,17]$. There is a range of external factors influencing these returns, from meteorological conditions to provision of flexibility by other parties, such as other business also offering DSR or companies offering flexibility from other technologies like electricity storage [21,34].

Given the differences between EE and DSR, although the EE framework can help inform the analysis of barriers to DSR, the individual barriers cannot be transferred from one technology to the other [21]. The specific barriers and their relevance to EE and DSR are likely to be different.

This article aims to explore and identify barriers to the participation of large commercial and public sector organisations in explicit DSR using the UK as a case study. DSR can be 
categorised as implicit (also known as price-based DSR) and explicit (also known as incentive-based). Implicit DSR refers to 'changes in electric usage by end-customers from normal consumption patterns in response to changes in the price of electricity over time' [35] and it is mostly used to smooth peak demand. Explicit DSR is 'committed dispatchable flexibility that can be traded (like generation flexibility) on the different energy markets' [36]. In explicit DSR, electricity end-users agree to temporarily alter their consumption within preagreed parameters such as response volume and response duration, in response to an external request. They participate directly or via a third party, such as an aggregator, in electricity markets where their 'DSR resources' are traded. The main purpose of explicit DSR is to address imbalances in the system.

The UK was one of the first European countries to open its markets to DSR [37]. Currently, there are several commercial firms and public sector organisations that participate in DSR, and thus the implicit assumption in this paper is that for this sector, it can be profitable to participate in DSR. The focus is on organisations with little or no experience of DSR, which represent most electricity users in the commercial and public sector. The literature reviewed includes policy papers and publicly available reports of surveys, DSR trials and interviews with electricity end-consumers and other stakeholders. Further details of the literature used can be found in the table in the appendix.

This article contributes to the literature on DSR by exploring the participation of a sector which to the best of our knowledge has been largely ignored in the existing literature and by focusing on barriers at the level of the organisation, rather than the site, as it is generally the case in other studies of DSR barriers. The findings of this paper can inform assumptions used in modelling the DSR potential of the commercial and public sector and the design of a regulatory framework that enables the participation of non-energy intensive firms in DSR.

This paper is structured as follows. Section 2 reviews the academic literature on DSR barriers and provides background information on DSR in the UK. Section 3 discusses the conceptual framework. Sections 4, 5, 6 and 7 examine barriers to DSR from the perspective of orthodox economics, organisational theories, BE and social practice theory. Section 8 concludes by summarising our findings and discussing policy and research implications.

\section{Background}

\subsection{Previous work on barriers to DSR}

The literature has identified three broad groups of barriers to the deployment of DSR. First, there are technology-related barriers [20], such as the lack of standardisation and protocols, and the additional investment requirements [3,5,38,39]. It is difficult to establish a business case for investing in DSR because establishing the value of DSR is not straightforward. Deciding who should pay for any necessary investments is equally problematic as the benefits of DSR are spread amongst different actors [3,5,38-40].

Second, existing market structures and regulatory frameworks hinder the deployment of DSR $[3,11,32,41]$. Several authors have examined the difficulties of integrating DSR resources into existing markets whilst maintaining system stability $[10,11,33,42]$. Others have identified DSR barriers to entry resulting from the design of existing markets which can fail to provide a level playing field to all participants [18,43-47]. 
Third, there are barriers regarding the electricity end-user, whose participation is decisive for the success of DSR $[3,14,32,48]$. Consumers are affected by the technology and regulatory barriers outlined above, but they are also seen as a barrier in themselves. There is considerable uncertainty as to how much DSR resource we can expect as electricity consumers form a highly diverse and distributed resource[3]. Also, whilst the advantages of DSR for the system are generally agreed, the net benefits for individual consumers are less straightforward [48], and even when financial gains of participation are clear, conventional economic models cannot always predict the response of energy users as DSR is not necessarily consumers' primary concern[32]. The issue addressed in this article-exploring factors that influence end-user participation in DSR - concerns one of the fundamental questions regarding the deployment of DSR.

As shown in Fig 1, electricity end-users can be categorised in three groups: industrial, commercial and residential [32,49,50]. A large chunk of the literature focuses on the residential sector [31,51-54], noting that there may be a considerable disconnect between the technical potential of this sector and the actual ability to provide flexibility to the system, as this is also influenced by social practices [55-60]. There are also several studies about industry, which have examined barriers to the realisation of the full technical potential of this sector, noting that key constraints are the criticality and technical requirements of the production process $[21,32,34,61,62]$. Regarding the commercial sector, however, there has been remarkably less work.

The term 'commercial and public sector' is used in this article to refer to organisations that work on what is commonly known as 'services'. The two sectors are grouped into one as their use of electricity is similar; electricity consumption is mostly related to building occupancy, comprising cross-sectional technologies such as heating, ventilation and air conditioning (HVAC), lighting, catering and refrigeration. This approach is consistent with the DSR literature, which commonly refers to commercial firms and public sector organisations as the 'commercial sector' $[32,49,50]$. In the UK, official data sources on energy consumption in commercial and public sector organisations are found under two categories: the 'services sector' (Digest of UK Energy Statistics - DUKES [63], and the 'non-domestic sector' (BEIS - Building Energy Efficiency Survey [64]). The 'services sector' also includes 'agriculture', which in 2016 was responsible for $1 \%$ of total electricity demand in the UK [63]. The 'non-domestic sector' refers to energy use in buildings, including buildings in the industrial sector. Most of the energy use in non-domestic buildings, however, occurs in the services sector, which is responsible for $84 \%$ of total energy use in nondomestic premises [64].

The commercial and public sector has the technical capacity to provide significant amounts of flexibility to the system. In Europe, it has been estimated that the theoretical potential of this sector is of a similar order of magnitude as that of the residential and industrial sectors [15]. In the USA, some studies suggest that commercial buildings' potential available flexibility corresponds to $70 \%$ of the total regulation capacity needed in the country [17]. 


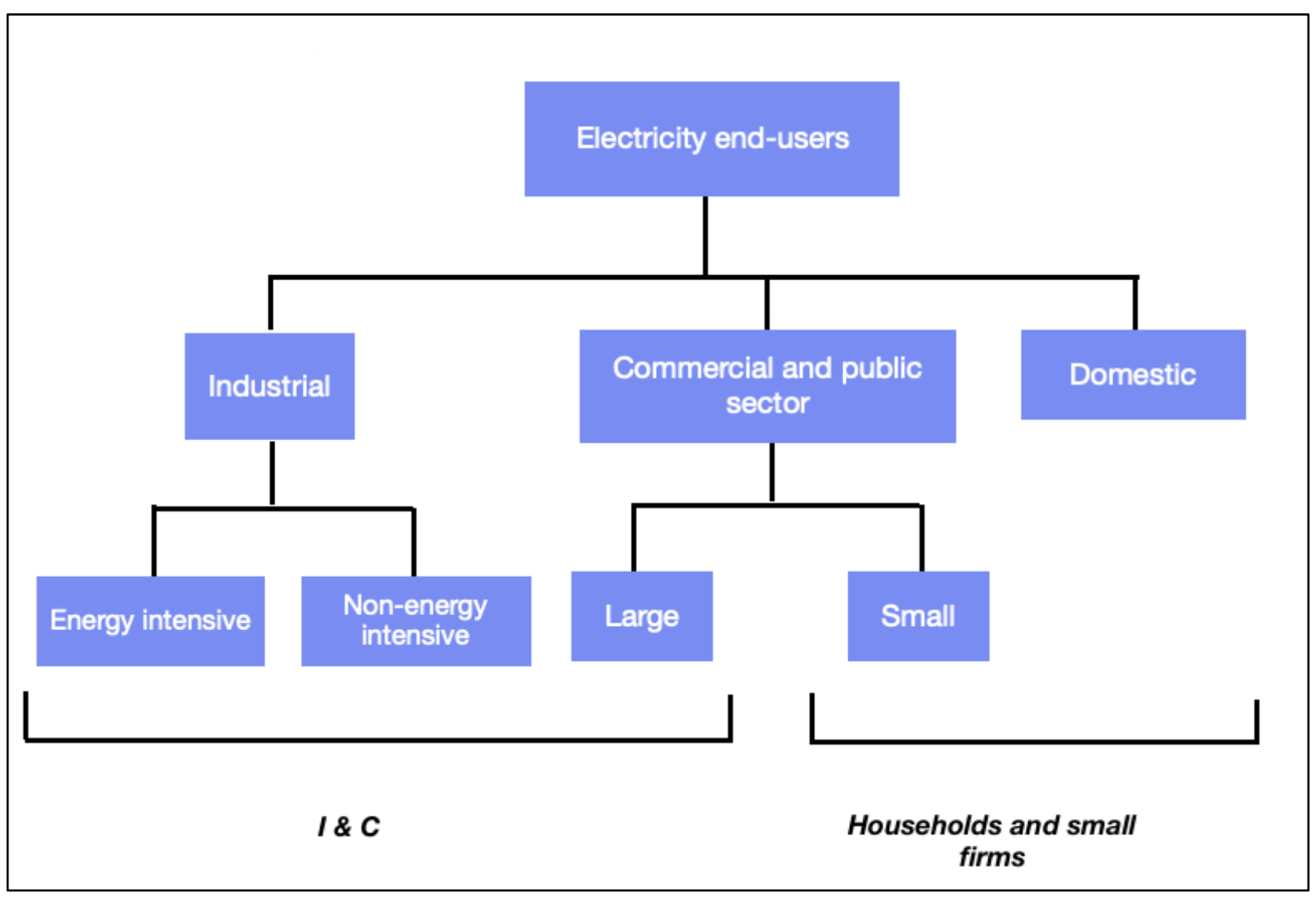

Fig. 1. Electricity end-users' categorisation

Existing studies on commercial firms and the public sector tend to focus on technical and regulatory aspects of DSR participation, such as the development of control systems to manage buildings' flexibility $[65,66]$; the flexibility potential of different appliances such as elevators and heating, ventilation and air conditioning (HVAC) $[17,67,68]$; and, the way in which the regulatory framework constraints the provision of DSR [69-71]. Whilst this literature is useful to understand the fundamental barriers to the uptake of DSR in the sector, it tends to focus on barriers in buildings or individual sites, and thus overlooks that energy related decisions are often taken at the level of the firm and affected by factors pertaining to the firm rather than the sites. Studies on the Industrial and Commercial sector (I\&C), refer to firms rather than sites. However, this literature assumes that large commercial and industrial firms face similar types of issues regarding DSR [3,62,72-75]. The implicit and sometimes explicit assumption is that whilst households are influenced by factors other than price, firms' decisions are mostly based on financial considerations regarding energy costs and benefit. Where participation in DSR is technically possible, an oft mentioned explanation for low levels of engagement in the commercial sector is lack of awareness of the opportunities of DSR [72,75].

By comparison with smaller electricity consumers, such as households or small businesses, I\&C organisations consume much larger amounts of electricity. However, large commercial organizations represent a very distinct group from that of energy intensive industrial firms. First, the industrial sector uses energy mostly for productive processes whilst the commercial and public sector consumes energy in relation to building occupancy, including lighting, HVAC, refrigeration and IT services (Fig. 2.). From this follows that although the aggregate load of large electricity consumers in the commercial firm and public sector organisations can 
be substantial and occasionally comparable to that of energy intensive firms, individual loads are smaller than those of industry as they are dispersed amongst different sites and appliances (Fig. 2). Second, costs of participation in explicit DSR is very different for the commercial and industrial sectors $[50,76,77]$. DSR participant costs include initial costs, which refer to the cost of investing in enabling technology and establishing a response plan, and activation costs, which are the costs incurred when they respond to a DSR request [35]. For energy intensive industries, the activation costs tend to be the most relevant ones, as they normally have the necessary metering and communication technology in place, whereas for commercial firms and the public sector the initial costs of updating their existing equipment or investing in additional technology represent the largest share of the cost of participating in DSR [76].

As this section has shown, although there is a significant body of work on barriers to DSR, there is no study that examines the specific barriers that impact on the commercial and public sector, particularly on large organisations.

\subsection{DSR in the $U K$}

In the UK, the commercial and public sector is responsible for approximately as much electricity consumption as the industrial sector, as well as for $30 \%$ of peak electricity demand [78].

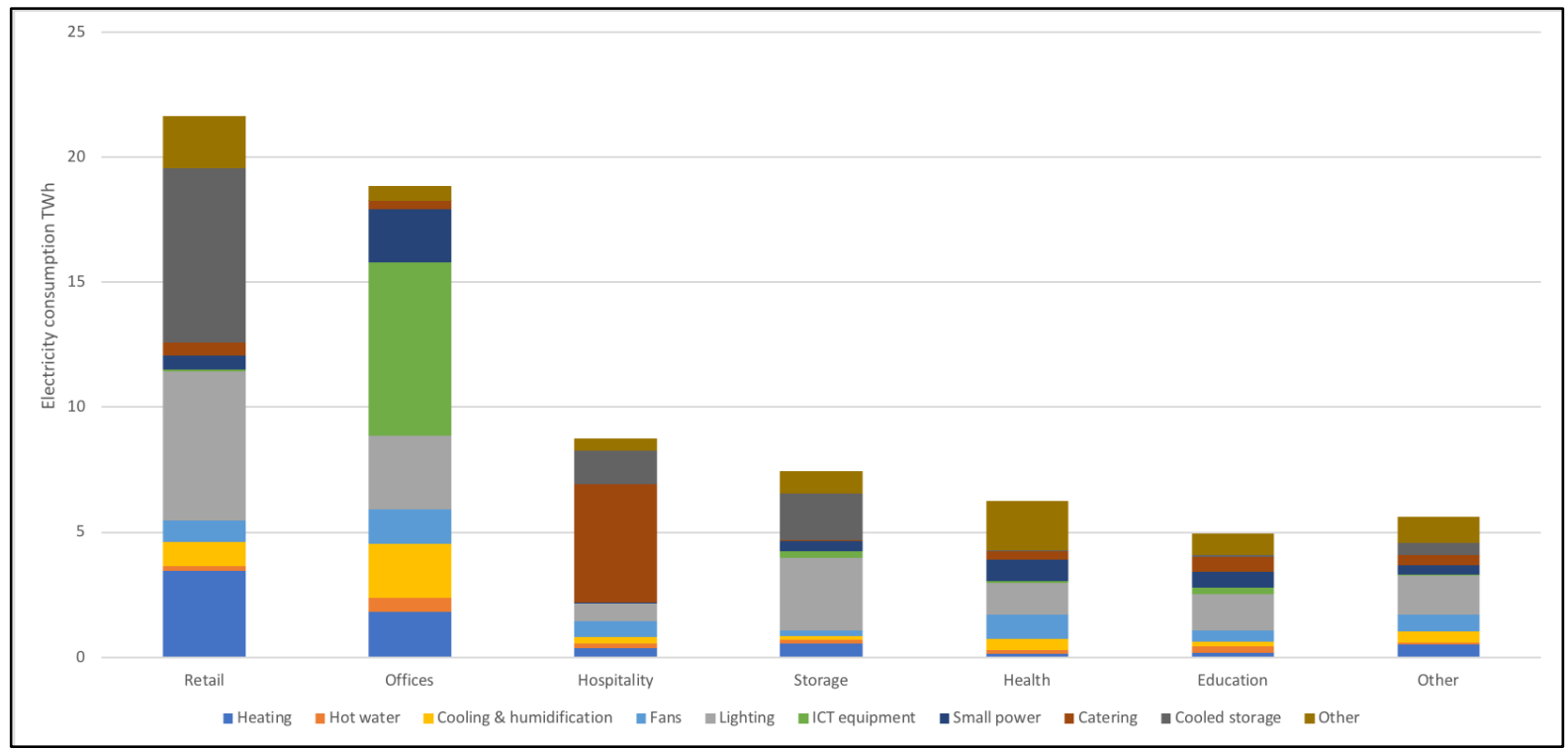

Fig. 2. Electricity consumption in the non-domestic sector by sub-sector and by end-use in England and Wales 2014-15

Source: Based on Building Energy Efficiency Survey 2014-15 [64]

As shown in Fig. 2, retail and offices are the main electricity consumers, each responsible for $17 \%$ of electricity consumed in the sector; health and hospitality together consume $22 \%$ [64]. The most common end-uses of electricity are internal lighting, followed by cooled storage and ICT equipment [64]. 


\subsubsection{Defining large organisations}

In this article, the term 'large organisations' or 'large firms' is used to refer to organisations (or firms) that have the basic equipment for participation in DSR and that have multiple sites, such as supermarket and retail chains, financial services companies, rail operators, large offices, hospital, universities and large local authorities. This use of the term is based on the different definitions of 'large firm' in the energy literature, summarised in Table 1. The UK energy regulator Ofgem defines large I\&C consumers as those that have historically had halfhourly metering facilities [19], thus sites with a peak load usage above $100 \mathrm{~kW}$ [79]. In terms of turndown potential, however, the minimum load for turndown potential per site has been estimated to be $200 \mathrm{~kW}$ [80]. Some of the statistics used here refer to large firms as those that have more than 250 employees [64], which generally corresponds to having peak demand of over $1 \mathrm{MW}$ [81]. In terms of energy policy, another criterion is energy consumption - the threshold for participating in the Carbon Reduction Commitment, a policy aimed at nonenergy intensive large companies, is approximately $6 \mathrm{GWh}[82,83]$.

\section{Table 1}

Large organisations in the commercial and public sector - indicative values.

\begin{tabular}{lll}
\hline Features & Large firms' features & Sources \\
\hline Control equipment & Most or all sites half hourly-metered & {$[19]$} \\
Peak load per site & Over 100 kw - over 200 kw & {$[79,80]$} \\
Number of employees & Over 250 & {$[64,83]$} \\
$\begin{array}{l}\text { Annual electricity } \\
\text { consumption }\end{array}$ & Over 6 GWh & {$[82]$} \\
$\begin{array}{l}\text { Peak demand } \\
\text { (organisation) }\end{array}$ & $\begin{array}{l}\text { Between 1 MW and 50 MW, with } \\
\text { some large retailers having over 50 }\end{array}$ & {$[81]$} \\
\hline
\end{tabular}

In the UK, large organisations are the largest consumers of electricity in the non-domestic sector, accounting for nearly 48,000 GWh (Small and Medium Size enterprises - SMEs consume slightly over 30,000 GWh) [64]. Large firms are also responsible for nearly half of all the floor area in non-domestic buildings [64]. In some sectors, namely health, education, storage and offices, large organisations own most of the floor area [64]. Amongst large companies, the most significant energy users are offices $(20 \%$ of total electricity consumption by large companies), followed by health (18\%), retail (17\%) and education (12\%) [64].

\subsubsection{The UK regulatory framework and levels of participation in DSR}

For commercial and public sector organisations to provide flexibility services, they need to be authorised to participate in electricity markets. It is also crucial that aggregated demand is encouraged, as individual loads in this sector are often below the threshold for participation in electricity markets $[18,37]$. Equally significant is the status of independent aggregators, firms whose role is to coordinate individual flexibility loads in exchange for a percentage of the DSR revenues and trade the aggregated DSR resource in electricity markets $[37,45,84]$. 
The UK is one of the few European countries whose market and regulatory framework enables the participation of the commercial and public sector in DSR [37,45]. In the UK, aggregated loads are enabled in the balancing market, and until recently were also formally allowed in the capacity market. Independent aggregators can participate in both balancing and capacity markets $[9,37,45]$, and follow a voluntary code of conduct that provides a common set of standards for potential DSR providers to assess their services [85].

Commercial firms and public sector organisations participate in DSR programmes and represent approximately a third of aggregators' portfolio [86].

Despite the above provisions, there is a significant gap between the commercial and public sector's potential for providing DSR services, and its levels of participation in DSR. Studies indicate that this sector could provide between 1.2 GW and 4.4 GW of demand-led DSR [78], with more recent research suggesting a potential of $1.7 \mathrm{GW}$ [87]. Regarding generator-led DSR, we could not find estimates discriminated by sector. However, based on the number of back-up generators in the UK, it has been estimated that the total potential is over $5 \mathrm{GW}$ [87]. Organisations such as hospitals, data centres, banks and some large commercial offices have back-up generators to ensure that critical loads - like medical equipment or servers - are not interrupted in the event of a power supply outage [78].

Levels of participation in DSR programmes are relatively low. The commercial and public sector accounts for less than a third of a total of $2.7 \mathrm{GW}$ of DSR, while industry - which has a similar level of electricity consumption - accounts for the other two thirds [63,77]. Only $10 \%$ of commercial firms and public sector organisations, participate in DSR [19].

\subsubsection{Routes to participation in DSR}

In the UK, large firms have access to both implicit and explicit DSR [19,38]. They have access to time-of-use tariffs and can also reduce their electricity bills by lowering their distribution and transmission network system charges [19]. The latter requires reducing consumption from the grid during the three yearly peak demand or 'Triad' periods. Suppliers notify large users up to one day in advance when one of the triads is expected to occur, and companies can then reduce their actual consumption or use a back-up generator for the duration of the triad [88]. Triad avoidance - a type of critical peak pricing [38] - is a popular participation route as it has been around for nearly two decades and the requirements for participation are less challenging than those of other alternatives [81,89]. Businesses do not have to agree beforehand to a specific reduction in electricity demand, but if they lower their consumption when warned of a triad period, they benefit from a significant reduction in their electricity costs. In 2016 and 2017, Triad avoidance was 2 GW [86]. Regarding explicit DSR, businesses can participate in the National Grid balancing services, providing frequency response and reserve services. They mostly participate through Short Term Operating Reserve (STOR), which like Triad avoidance is an established service and has less challenging technical requirements than other more financially attractive products [86]. In 2016, 2.1 GW of DSR participated in the UK balancing and ancillary markets [77]. This volume corresponded to a value of $£ 11$ million or $4 \%$ of the market value of balancing services [77]. Product complexity is a frequently mentioned criticism, which the National Grid has tried to address [86,90].

Until recently, DSR could also participate in the GB capacity market. In return for a retainer payment, they need to be available for providing DSR services at a future date, when the system is tight. There are auctions for both generation and demand-side providers where the 
National Grid buys capacity ( $£ / \mathrm{kW} /$ year) four years ahead of delivery; in the $2017 / 18$ auction, $1.2 \mathrm{GW}$ of DSR capacity secured agreement for delivery in 2021/22, totalling 2.4 of total secured capacity [91]. To facilitate the participation of DSR in the capacity market, the NG also held Transitional Arrangement Auctions in 2015 and 2016, for delivery on the following year. Although the capacity market allowed DSR participation, alleged discrimination against DSR providers has led to its suspension. Criticisms included contract length and costs, which were more onerous on DSR providers than on generators [2,92].

Table 2

DSR volumes in the UK (unit GW).

\begin{tabular}{lll}
\hline Market and products & $2016 / 17$ & $2017 / 18$ \\
\hline Triad avoidance & 2.0 & 2.0 \\
Balancing markets & 2.1 & 2.28 \\
Capacity markets & & \\
T-4 1 Auction & 1.4 & 1.2 \\
$\mathrm{~T}-1_{2}$ Auction & 0.209 & 0.443 \\
Transitional Arrangements & 0.312 & n/a \\
\hline
\end{tabular}

Sources: [77,86,91,93]

Note 1: T- 4 - auction held four years before delivery;

Note 2: T-1- auction held one year before delivery.

To summarise: the UK makes an interesting case study to examine the commercial and public sector partly because it is one of the few countries where the regulatory framework allows for their participation in DSR programmes, and it has done so for some time. The engagement of commercial firms and the public sector in DSR, however, remains low. In the next section, we elaborate on the theoretical lenses used in this article to identify factors that may impede uptake of DSR.

\section{Using a multidisciplinary approach}

This article uses a multidisciplinary theoretical framework comprised of four different theories - neoclassical economics, behavioural economics, organisational theories and social practice theory. Each of these theoretical perspectives has different underlying assumptions about the autonomy of individuals and therefore emphasise different types of barriers [94].

Orthodox and behavioural economics focus on individual motivations and behaviours, albeit each makes very different assumptions about the 'rationality' of individuals [95,96].

Organisational theories include both agency-based economic theories and socio-political perspectives that emphasise social structure, but despite their differences, they tend to share a common understanding of organisations as complex entities where investment decisions are not solely based on the profitability of individual projects but are also the result of interactions amongst different actors [97-99]. This understanding of organisations is key to the current analysis as the focus is on large organisations which involve many different actors with decision-making responsibilities. Practice theory is a socio-technical approach and therefore uses very different assumptions to that of economics. They consider economic explanations to be excessively focused on individual motivations, arguing that individuals operate in a socio-technical, political and institutional context which shapes and constraints their decisions about energy use [100-102]. From a socio-technical perspective, reducing 
energy consumption or decarbonising the power system requires system changes rather than solely the removal of individual barriers $[100,103,104]$.

Economics and organisational theories are often combined to explain the EE gap $[22,99,105]$ and have also been jointly used to explain barriers to DSR in industry [21]. Although it is less common for studies to combine economic and socio-technical approaches, there are advantages to combining these two perspectives. A study by Palm and Thollander [101] shows how barriers to industrial efficiency operate differently in different social contexts and suggests examining barriers within the socio-technical regime in which they operate. Banks and Redgrove's [106] examination of energy efficiency in the non-domestic sector also uses a framework which integrates accounts of behaviour which have economic rationality as their basis but are also the outcome of the social and cultural context. In the realm of DSR, Good et al [20] provide a review and analysis of barriers to DSR which is grounded on economic, behavioural and organizational theories, but also includes elements of a more 'sociotechnical' understanding impediments to DSR. This approach enables a more comprehensive review of DSR barriers as it enables the inclusion of barriers operating both at the level of the individual energy user and that of the system.

\subsection{Conceptual framework used in this paper}

In this paper, rather than integrating perspectives with very different assumptions about the role of individual, structure and the role of the wider context, we have chosen to provide both perspectives separately.

The first part of the analysis focuses on individual decision-making since despite different levels of contextual constraints decisions within firms are taken by individuals $[20,106]$. The second part of the analysis uses a socio-technical approach - social practice theory - to examine the constraints that the wider context can impose on DSR related decisions. Social practice theory argues that decisions about energy use and by extension about energy efficiency occur within a social context [102]. Energy is used for accomplishing social practices, at home but also at work [107]. The patterning of social life is a consequence of routine, collective and conventional nature of consumption [108]. From social practice theory, the timing of energy demand can be defined as the result of the socio-temporal organisation of daily practices. From this it follows that decisions about energy investment are not solely determined by an evaluation of a project's costs and benefits, and by the decision-makers' individual motivations, but also by what is feasible and expected within institutional settings as well as by the necessary energy-using technologies [109].

Our use of the concept of barriers is grounded on Sorrell's definition. Sorrell et al [99] define a barrier as "a postulated mechanism that inhibits a decision or behaviour that appears to be both energy efficient and economically efficient". Applying this definition to DSR, we can say that a barrier is "a mechanism that inhibits participation in a DSR programme that appears to be both technically feasible and profitable". We use the term 'barriers' as conceptual tools that help us organize and guide our review of the difficulties faced by nonenergy intensive organizations.

Table 3

Conceptual barriers reviewed in this paper. 


\begin{tabular}{|c|c|c|}
\hline $\begin{array}{l}\text { Orthodox } \\
\text { economics }\end{array}$ & $\begin{array}{l}\text { - Hidden costs } \\
\text { - Risk }\end{array}$ & $\begin{array}{l}\text { Sorrell et al, 2004, 2011[23,99] } \\
\text { Cagno et al, } 2013[22]\end{array}$ \\
\hline $\begin{array}{l}\text { Behavioural } \\
\text { Economics }\end{array}$ & $\begin{array}{l}\text { - Bounded rationality } \\
\text { - Inertia and status-quo-bias }\end{array}$ & $\begin{array}{l}\text { Simon, } 1997 \text { [110] } \\
\text { Tversky and Kahneman, } 1974 \text { [111] } \\
\text { Pollitt and Shaorshadze, } 2011 \text { [96] } \\
\text { McNamara and Grubb, } 2011 \text { [95] }\end{array}$ \\
\hline $\begin{array}{l}\text { Organisational } \\
\text { perspectives }\end{array}$ & $\begin{array}{l}\text { - Complexity of decision - } \\
\text { making } \\
\text { - Low status of energy }\end{array}$ & $\begin{array}{l}\text { Cooremans, 2011, } 2012[24,27] \\
\text { Decanio, 1998, } 2001[26,112]\end{array}$ \\
\hline $\begin{array}{l}\text { Social practice } \\
\text { theory }\end{array}$ & $\begin{array}{l}\text { - The timing of demand } \\
\text { - What energy is for }\end{array}$ & $\begin{array}{l}\text { Walker, } 2014[113] \\
\text { Guy, } 2006[102] \\
\text { Shove, } 2010[114]\end{array}$ \\
\hline
\end{tabular}

The conceptual barriers used in this study (Table 3) were chosen based on three criteria. First, we focused on 'internal barriers', that is, barriers that originate within the firm, such as the behaviour of decision-makers within the organisation, rather than on 'external barriers', such as distortions in energy prices or the behaviour of energy suppliers [22]. We thus take the external setting - e.g. energy prices, regulatory framework and market structures - as given, which is the approach taken by Sorrell et al [99]. Second, from each theoretical framework, we focused on those barriers that are most typical of large non-energy intensive organisations. From orthodox economics, we focused on hidden costs and risks, rather than 'access to capital' and the 'landlord-tenant' (split incentive) as these tend to be more of a barrier in smaller firms $[22,64]$. From organizational perspectives, we focus on the complexity of decision making which is particularly relevant to large organisations and the low status of energy matters, which is very characteristic of non-energy intensive organisations [83]. Third, we only cover barriers for which we could find enough information in the existing literature.

The different theoretical lenses are presented in the following order: orthodox economics, which focuses on barriers directly related to the individual project; organisational theories which focuses on how the characteristics of the organisations may act as barriers to energy projects; BE which focuses on the barriers faced by individuals within organisations; and social-practice theory that examines the contextual constraints within which decision-makers operate.

\section{Orthodox Economics}

\subsection{Hidden costs}

Hidden costs can be defined as costs that are not conventionally incorporated in engineeringeconomic studies of energy projects [23] but which firms include in their assessment of energy investments. The literature on DSR indicates that there are several costs associated with the participation of commercial firms and public sector organisations in DSR which 
existing studies on DSR potential overlook. This suggests that unless hidden costs can be reduced, the ability of this sector to provide flexibility services to the system might have been overestimated.

Estimates of DSR potential often neglect participants' costs or fail to appropriately differentiate between the costs incurred by industrial firms and those faced by commercial and public sector organisations. Some estimates focus on technical potential without including the costs incurred by DSR providers [15,78,115-117]. Studies of economic potential vary in their approach to participants 'costs. A study by Charles River [77]examines the economic potential of DSR, but it focuses on the costs and benefits for the system rather than the participants, using the technical potential for DSR to estimate its economic value for the market. Other studies of economic potential differentiate between process technologies, used in industry, and cross-sectoral technologies used in industry, commerce and households [50,118]. Gils [118] assumes the same investment costs for cross-sectional technologies in industry and commerce. Steurer [50] includes both investment and annual costs for crosssectional technologies and assumes that variable costs are negligible. A study assessing the potential of DSR in the UK incorporates the costs of building and operating DSR capacity in its approach [119]. However, they note that it is difficult to estimate the costs in I\&C demand-led and generation-led DSR as 'relatively little information is available regarding the costs of setting a site for demand side response' [119].

A study of costs and benefits of DSR [48] makes a similar observation, noting that it was not possible to obtain quantitative information about participant costs. However, to participate in DSR programmes, commercial firms and public sector organisations incur several costs (see table 4), such as those of investing in additional equipment or of upgrading their existing equipment $[81,120]$. These costs can vary considerably between organisations $[109,119]$ and can be very high $[76,81,89]$. In addition to the capital costs, there are also hidden production costs such as time spent finding suitable equipment for participating in DSR, which have been highlighted as one of the main barriers to participation [121]. Equipment may be unsuitable because it cannot meet DSR performance requirements, such as responding to a DSR signal within a specified timeframe or because it is unable to interact with the businesses' existing equipment. Other hidden production costs are the inconvenience of installing new equipment, which may have to be done outside business hours to avoid disruption [115]. For commercial firms and public sector organisations, both capital and hidden production costs represent more of a barrier than for companies operating in energyintensive sectors as costs per MW are typically higher for DSR types with relatively low capacity per component, i.e. refrigeration and chillers, pumps and building HVAC. The larger industrial DSR types benefit from economies of scale and typically already have the necessary metering and control systems in place as it is needed for process control and routine energy management [76].

Market transaction costs (TCs) are the costs of gathering information about products and suppliers, managing contracts and administrative procedures for external transactions; they are primarily influenced by the market and therefore by factors outside the businesses' control [99]. Deciding whether to participate in DSR requires a significant investment of time and resources. Organisations need to collect data on their electricity use; identify sites which can flex their electricity consumption without impacting on their core business, assess the suitability of on-site generators for participation in DSR programmes, and assess the costs and benefits of the various options [122]. Assessing options and comparing their net returns 
can be time-consuming as DSR markets are complex and difficult to understand $[28,90]$. Although recently simplified, the National Grid (NG) balancing service has 11 different products to choose from, each having specific requirements regarding minimum contribution, notice period, duration, regularity, and procurement process and contract duration. Choosing the correct product is critical, as revenues can vary considerably [77].

If after the initial assessment, a firm chooses to proceed, there are further legal and administrative procedures [50]. A study of non-energy intensive firms noted that complex management requirements led to additional costs and that administrative overhead costs could be hard to foresee if companies lacked experience in DSR provision [123]. At stakeholder meetings facilitated by the NG, businesses made similar observations, commenting that participation in DSR was 'unduly burdensome, with substantial paperwork' [124]. Administrative requirements are particularly onerous for the commercial and public sector. For example, to participate in the Capacity Market (CM), sites need to provide a line diagram showing all the loads connected to the service. The cost of preparing the diagram increases with the number of loads and buildings tend to have a higher number of loads than individual production processes [125]. For multi-site organisations, the non-standardization of contracts adds further complexity [124].

\section{Table 4}

DSR participants' costs.

\begin{tabular}{|c|c|}
\hline Type of costs & Cost examples \\
\hline Capital costs & $\begin{array}{l}\text { - Investment in communications, control and metering } \\
\text { equipment } \\
\text { - Updating existing equipment, including back-up generators }\end{array}$ \\
\hline $\begin{array}{l}\text { Hidden } \\
\text { production costs } \\
\text { (of DSR) }\end{array}$ & $\begin{array}{l}\text { - Production interruptions to allow equipment installation } \\
\text { - Overhead costs to allow equipment installation outside } \\
\text { business hours } \\
\text { - Searching for suitable equipment }\end{array}$ \\
\hline Transaction costs & $\begin{array}{l}\text { - Gather sufficient information on DSR to allow initial decision } \\
\text { to participate } \\
\text { - Choosing aggregator and negotiating contract } \\
\text { - Managing contracts } \\
\text { - Collecting half-hourly electricity usage data from different } \\
\text { sites }\end{array}$ \\
\hline Activation costs & $\begin{array}{l}\text { - Up to } £ 15 \mathrm{MWh} \text { for ventilation loads in non-domestic } \\
\text { premises }\end{array}$ \\
\hline
\end{tabular}

Source: Authors, based on [28,50,127,77,81,90,99,109,119,125,126].

Activation costs in the commercial and public sector are considerably lower than those generally found in the industry, and consequently, some models assume them to be negligible [50]. The activation costs for industrial processes can range from $£ 80$ to $£ 400$ per MWh, whereas for cross-sectional technologies such as HVAC, they are $£ 15 \mathrm{MWh}$ or less [77]. However, though activation costs in non-domestic premises are much lower than those in 
industrial sites, they are nevertheless likely to play a role in firms' evaluation of DSR proposals.

Most large I\&C businesses participating in DSR use aggregators. Some studies indicate that $74 \%$ of organisations providing DSR resources to the balancing and capacity markets do so through aggregators [19]. Aggregators absorb some of the market TCs: They provide information on DSR options, assess the sites' technical capacity and identify the products that best match the capabilities of the company [80]. Aggregators also cover the administrative requirements of DSR participation and manage the market bidding [128]. However, engaging an aggregator reduces the financial benefits of DSR, as they take a share of the revenue estimated to range from $10 \%$ to $50 \%$ [129]. There are also TCs involved in choosing an aggregator and in negotiating, managing and monitoring their contracts. The fact that most firms choose to engage aggregators, despite the costs in terms of lost revenue and TCs involved, suggests that market TCs of participating in DSR are high.

\subsection{Risk}

Rational responses to risk include requiring more stringent investment criteria, postponing investment and deciding not to invest [99]. Economic models capture some risks such as those that originate from uncertain revenue streams but not necessarily other more difficult to estimate risks such as the perceived risks of investing in new but technically proven technologies. However, whichever the source of risk to DSR participation, if businesses perceive it to be high, this can act as a barrier to participation.

The main risk associated with DSR is that it may disrupt organisations' core business. Interviews with energy managers concluded that the fear of reduced service levels is so high that unless there are strong assurances that business would not be disrupted, responders prefer not to participate in DSR [78]. A more recent survey of large businesses noted that independently of whether respondents participated or not in DSR programmes, 'risk to the business' was the most frequently mentioned barrier to DSR [19]. In a yearly survey carried out by a DSR specialised publication, 'disruption and potential impact on business performance' was one of the three most frequently mentioned barriers in three consecutive years $[81,125,130]$.

Firms' concern that participating in DSR is risky to their core business may be due to DSR being an unfamiliar concept. The smart grid can be an abstract concept operating in the background and difficult to understand without basic knowledge of the energy market [123]. Uncertainty over standardisation and lack of guidelines about technical and safety issues further contributes to heighten perceptions of risk [50]. A frequently mentioned barrier in business surveys and interviews is the reluctance of end-users to cede control of their organisations' internal electricity systems to a third party. Automation is particularly important for the non-domestic sector. It allows businesses to access a wider range of products and more profitable options than what is possible without automation [109]. Automation also reduces aggregators' risks and therefore, their ability to help businesses participate in DSR. In the 2017 Energyst survey [81], only 13\% of respondents mentioned third party control as a reason for not participating in DSR. However, most other studies reviewed note that consumers are at best cautious about automation, especially if they lack prior experience with the process $[28,78,115]$. In the above-mentioned survey of large I\&C firms, third party control was the most frequently mentioned barrier for not participating in DSR - over $50 \%$ of respondents considered it a problem [19]. 
The second most common risk associated with DSR is the uncertainty of financial returns, which partly results from the characteristics of DSR markets. In electricity markets, financial returns for DSR products are partly dependent on the system needing additional flexibility and on the available flexibility options, thus determined by factors outside the control of individual businesses. Furthermore, some markets such as the CM, use auctions and therefore, the financial return for products is only known once the market clears, adding a further layer of uncertainty. In the CM, contracts for DSR are for one year only, which impacts on the possibility of spreading revenue risk over time. Potential investors interviewed for an assessment of the CM reported that these uncertainties acted as barriers to participation [129]. Similar observations were made in a study of German firms, that noted that a central drawback of DSR was that prices could not be predicted reliably [123].

Some of this uncertainty, such as those inherent in auctions, may be acceptable in other areas of the business but in the case of DSR initiatives, lack of secure financial returns can hamper energy managers' efforts to enlist the support of other decision-makers within the firm.

Participants in stakeholder meetings with the NG have reported that the risk involved in DSR investments has made it difficult to secure internal buy-in and in some cases resulted in companies favouring alternative programmes, such as LED lighting replacement [131]. The combined effect of high market TCs and other hidden costs, together with revenue risk may explain why some surveys have found that businesses require higher financial returns than currently being offered by the market $[19,81,132]$.

\section{Organisational Perspectives}

\subsection{Decision making in large organisations}

Organisations can be described as networks formed by different actors, with diverse and often conflicting priorities [112]. Especially within large organisations, decision chains can be very highly complex, requiring the approval of multiple parties to proceed with a project [64]. Proceeding with an energy project involves not only the energy manager but several decision makers. As energy is an issue that cuts across many activities, many energy projects require the agreement of individuals whose understanding of and interest in energy initiatives can vary considerably [133].

Regarding DSR investments, this means that even if the energy manager or person in charge of energy matters is well informed about the risk and financial profitability of DSR projects, they still require the agreement of the operational and financial departments as well as of the engineers or others in charge of the sites. Operational teams' primary concern is the potential impact of DSR on the business core operations [81,130], and their interest and knowledge of energy may be very different from that of the energy staff $[22,26,64]$. Site engineers may also be more concerned with the smooth functioning of the equipment than with potential gains from a DSR project [81]. Convincing colleagues of the value of a DSR investment can be at best very time consuming, as illustrated by the quote below.

"The onsite energy manager thinks DSR looks interesting and could provide revenue. They have to speak to the estates' team, who will look at the asset register. Then they have to get in touch with the finance guys to ask whether they can go ahead; there might be some invoicing arrangements, there might be funding required. Then they have to consult with the clinicians, who are acutely concerned about any break in supply. ... Lastly, somebody from 
procurement will need to get involved to choose the supplier that is offering the best value" (comment by interviewee [81]).

Persuading other decision-makers of the advantages of participating in a DSR project has high organisational transaction costs [99]. These include the time needed for championing DSR within the organisation, addressing engineers' concerns about the compatibility of DSR with existing equipment, evaluating operational teams' concerns about potential impacts of DSR on primary operations. It may also be necessary to identify the benefits of a DSR proposals for specific departments. If managers cannot appropriate the benefits of the investment, their interest in participating may be reduced (a problem of split-incentives within organisations). A DSR proposal may be financially attractive for the energy department and for the organisation as a whole, but the costs and risks be shared across the organisation [78]. Another source of organisational transactional costs is the need to collect and coordinate data from different departments and help negotiate individual site contracts.

Organisational transaction costs may help explain the long time it takes DSR buyers - such as Distribution Network Operators (DNOs) and aggregators - to procure DSR services $[81,89]$. According to a DSR trial by one of the DNOs, engaging a new customer may easily take a year or more [134].

\subsection{The low priority of energy matters within organisations}

In organisations where energy is not linked to the core business - either because energy costs are relatively low or energy is not part of the production process - non-essential energy projects are often not considered organisational priorities [22,83,135-137].

Energy is frequently a marginal issue in non-energy intensive firms such as those in the commercial and public sector, where energy costs are relatively low by comparison to other costs $[22,98]$. In the UK, in energy-intensive industries, energy costs make up $3.8 \%$ of operating costs, while in the non-domestic sector, energy accounts for $0.9 \%$ of operating costs [138]. In office spaces, rental costs [98] and staff wages [137] are considerably higher than energy costs. In large organisations, energy costs are often high in absolute terms, but in comparison with other internal costs, they are relatively unimportant $[83,136]$.

In industry, energy is part of the production process, and as such investments in energy efficiency are treated as core business investments. By contrast, in the commercial and services sector, energy consumption is part of 'generic' consumption, and the priority is to ensure that energy provides a service to the core business $[83,136]$. In sectors that deal directly with the public or that operate in sensitive sectors, energy projects can contribute to the environmental reputation of the firm; this makes energy more salient within the firm and therefore more likely to be treated as core business. However, when energy is not salient or fails to play a strategic role within the organisation, energy projects are considered less of a priority than projects that contribute directly to the core business [24,139].

Several studies on DSR mention the 'non-core business character' of energy and the resulting low priority that energy investments receive within an organisation as a barrier to DSR.

Respondents in a study evaluating the capacity market arrangements for DSR noted that since DSR was not core business, it could potentially be a 'risky distraction' [129]. A study exploring the potential of DSR in the non-domestic sector points out that since energy is not the focus of organisations in this sector, DSR is generally not a priority; in this study, the low 
priority of energy projects was the barrier that interviewees most frequently mentioned [119]. The low priority of energy is also considered a barrier to DSR in a study of London based companies[132], an analysis of non-energy intensive firms in Germany [123][88], and in interviews with DSR providers and utilities in the UK [81].

The low importance of energy within organisations can hinder the uptake of DSR in three ways.

First, in the commercial and public sector the net potential gains from DSR are lower than those of energy intensive sectors. Flexibility loads in commercial firms and the public sector are considerably smaller than those of large industrial sites; concurrently, the initial costs of participation, including both capital investments costs and hidden costs, can be significant. From a purely financial point of view, DSR is thus less attractive for organisations in the commercial and public sector than for those in energy-intensive industries. It is also worth noting that even if a company's overall consumption and potential flexibility is high, the flexibility per site may be much smaller. This point is illustrated by an interviewee in the Energyst [81], commenting that, for a large firm like a global bank, the returns from some of the most profitable DSR products may still not be considered worth the investment if the electricity consumption and potential flexibility at the level of the site are low.

Second, non-energy intensive companies allocate fewer resources to energy departments, thus have less capacity to evaluate energy proposals. In the UK, only $57 \%$ of large firms have a specialist energy manager and only a proportion of these are actively engaged in energy efficiency initiatives. The proportion of large companies with both the capacity and ambition to reduce energy consumption is 44\% [64]. These figures also include most industrial sectors; therefore, we can infer that the proportion of large commercial and public sector companies with the resources and the interest in reducing energy consumption is less than $44 \%$ of the total. Participating in a DSR programme has high transaction costs, which companies with under-resourced energy departments may be unable to afford.

Third, in commercial and public sector organisations energy issues are generally relegated to maintenance departments with little power and far away from the more senior decisionmakers $[22,101,133,137]$. Energy managers often do not wield enough power to gain the attention and support of more senior decision-makers within the organisation. This situation constraints energy managers' ability to take the necessary steps to participate in DSR - such as investing in new equipment or obtaining approval for DSR projects by other departments and hinders the progress of DSR related initiatives [20].

\section{Behavioural Economics}

Pollitt and Shaorshadze [96] and McNamara and Grubb [95] identify several concepts from behavioural economics that can help explain the energy efficiency gap. These studies focus on the behaviour of individual consumers rather than that of organisations but considering that within firms, decisions are taken by individuals, the concepts can also help understand energy-related decisions in businesses and public sector organisations [105,140]. In this section, we use the concepts of 'bounded rationality', 'loss aversion' and the 'status quo bias' to examine the choices that commercial and public sector organisations make about DSR. 


\subsection{Bounded rationality}

Bounded rationality means that individuals are rational but limited in terms of their attention capacity, their knowledge and their ability to forecast the future [110]. As they lack the time and resources needed to find optimum solutions, they resort instead to rules of thumb and aim for satisfactory rather than optimal outcomes energy [27,106,111]. There are two reasons why the concept of bounded rationality can help understand the limited interest in DSR by non-participating firms.

First, bounded rationality is most relevant for issues perceived as marginal to the core business [27], which as aforementioned in section 5.2 is often the case regarding DSR in the commercial firms and the public sector. Several studies have shown that in non-energy intensive firms, investments in energy projects are assessed and treated differently from investments in core business projects [24,27]. Pricing plays less of a role, and it is not as much of a determining factor for energy investments as it is in the energy-intensive sector [83,106,141]. Price is one of the main reasons for participating in DSR - several surveys have shown that the main reasons for organisations to participate in DSR are the potential financial gains [81,89]. However, on the other hand, decisions to participate are not necessarily based on assessments of the financial costs and benefits of participation or made using standard economic appraisal methods.

In commercial firms and the public sector, energy managers have less time to consider complex and non-essential energy projects; consequently, they may ignore such projects or assess them using heuristics rather than conducting an economic analysis of their potential [24]. In other words, the issue is not solely one of insufficient time to examine a DSR proposal but also of the criteria used to evaluate such a proposal. Likewise, decision-makers who are not energy experts may be unwilling to take the time to understand complex proposals and use heuristics to make their decisions. This problem is exemplified in a survey of mostly commercial firms carried out in London [132], were the energy managers with fewer resources made decisions about DSR based on perceptions such as potential impact on services, not being able to participate because of lack of back generation and the need to leave equipment running at all times influenced decisions not to participate in explicit DSR determined decisions. The same study noted that there was a risk that decisions about DSR were not taken on technical or cost-benefit grounds; instead, they were taken by people who lacked the time or inclination to understand them fully [132]

Second, the use of heuristics is prevalent during the initial phase of the decision-making process, such as when companies with little or no experience in DSR first consider a proposal for flexing their electricity demand in exchange for a financial payment. Cooremans [24], explains that decision-making is not a point in time but a process comprising three phases: identification or diagnosis, development (build-up of solutions) and selection, which involves the evaluation of different solutions and choices. Formal economic methods of assessment are frequently used during the selection phase. By contrast, during the identification phase, bounded rationality and the use of heuristics such as shortcuts and routines, and unconsciously searching for information to support existing views, play a more significant role and can distort decisions.

In the DSR process, the identification phase can consist of an initial contact by an aggregator offering to assess the costs and benefits of participating in explicit DSR. A study of aggregators' acquisition process found that during the two first stages of the selling process, a 
primary reason for sites not taking up DSR was lack of interest. By contrast, during the last two phases of the selling process, if sites chose not to participate in DSR, they provided specific reasons for their decision, such as the technical unsuitability of assets [80]. A possible interpretation for these results is that during the initial phases, decisions about DSR were taken without carrying out a detailed assessment of the aggregators' proposal but based on rules of thumb.

\subsection{Loss aversion and the status quo bias}

A central tenet of $\mathrm{BE}$ is that individuals estimate costs and benefits in relation to a neutral reference point. As people value costs more highly than benefits - they are 'loss averse' - if the costs and benefits of an action are the same in absolute terms, they will fear the costs more than they will value the gains and therefore will choose not to act [142]. Organisations' loss aversion can be described as a conservative bias - people are unlikely to get blamed for doing things in the traditional ways, but doing something new may carry a high personal risk of being blamed if it goes wrong [143]. Loss aversion can thus stop a firm from providing DSR, as even if the potential benefits are high, the risks involved carry more weight with the decision-maker.

The reference point against which individuals assess costs and gains is often the status quo. Individuals tend to show a preference for the status quo because the disadvantages of leaving tend to "loom larger than the advantages" [144]. Regarding DSR, a preference for the status quo would also result in non-participation in DSR programmes. Interviews with DSR stakeholders about businesses' provision of flexibility services mention inertia as a reason for preventing DSR projects from happening $[81,125,130,132]$. The term 'inertia' explains the inaction of companies when there are no other explanations for their lack of action, but inertia may also represent a preference for the status quo.

The 'status quo bias' can hinder the uptake of DSR for two reasons. First, DSR represents a radical departure from how consumers perceive energy use. Continuous access to energy is taken as a given. Flexing consumption in response to external signals can be perceived as a deviation from what - from an energy user's perspective - is a well-functioning system $[39,123]$. This is most likely to be the case with decision-makers other than energy managers. A comment by the person in charge of DSR for an international hotel chain illustrates this issue: the biggest challenge of implementing DSR is 'getting our internal audience to understand the concept of "turning down" at their peak operating times' [130].

Second, uncertainty enhances the attraction of the status quo, which, whatever its limitations, has the value of being known [105]. As aforementioned in section 4.2, there are considerable levels of uncertainty inherent in the design of the $\mathrm{CM}$, and some products of the balancing market. Frequent changes in legislation, perceived as part of a piecemeal approach to DSR, also add to feelings of uncertainty [145]. A survey of potential investors in the CM reported that lack of certainty about the future policy environment was one of the issues that needed to be addressed [129]. DSR is associated with many uncertainties and unknowns - auction prices, number of DSR events, the complexity of regulation, changes in policy and market regulations, access to electricity. If taken together, these uncertainties might result in perceptions of DSR being generally risky and hence reinforce the status quo bias.

In summary, while organisations use robust decision-making techniques to assess projects which are central to the business, for peripheral projects such as energy-related initiatives in 
non-energy intensive sectors, they often use heuristics instead. Issues of bounded rationality, loss aversion and the status quo bias may thus be significant for initial decisions on whether to participate in DSR.

\section{Social practice perspectives}

Socio-technical perspectives on energy demand point out that decisions about energy are 'an outcome of what energy is for' [113]. What people and organisations do - and what they use energy for - are seen as social practices. For example, energy can be used for cooking (including in the workplace), or commuting to work, or conducting meetings, all of which are examples of social practices $[107,146]$. These practices are embedded in social settings and temporal rhythms of everyday life and influenced by material arrangements [102,107,114]. For social practice theory, the central topic of enquiry is the social practice itself [107] rather than the individual, as it is the case in orthodox and behavioural economics, or the organisation, as it is the case with organisational theories. In this paper, however, and in line with other energy researchers [147], we take the insights of social practice to gain a better understanding of how time-shifting practices relate to the energy demand of different organisations. In the remainder of the section, we briefly discuss some ways in which social settings, temporal rhythms and material arrangements can influence the uptake or otherwise of DSR programmes in the commercial and public sector.

The setting for DSR, that is, whether energy consumption is taking place in a hotel for example, or in a school, can be used to show how feasible it is in practice to change demand in response to signals coming from the energy supply system [148]. Two identical office buildings (in terms of physical characteristics) can experience different levels of electricity demand at different times of the day depending on the activities taking place. Whether a building can participate in DSR depends thus on the technical characteristics of the building loads, on the purpose of electricity use in that building, and on the business sector where it operates. The practices taking place in the workplace are associated with different rhythms. Similar buildings will have different daily or yearly rhythms if they operate in different settings, which in turn will impact on when and how they can flex their consumption [78]. For instance, offices used in the education sector tend to have a typical nine-to-five routine while in the healthcare sector diurnal variations are lower. Schools are more likely to have yearly variations with higher occupancy during term time and less during the summer months than offices in banking. In hospital buildings, medical practices, rhythms of sequencing for treatment scheduling, and provision of care determine energy use [148].

A study of the DSR potential of individual loads in a hotel site demonstrates the relevance of material arrangements and of everyday social practices for determining the provision of DSR in commercial and public sector organisations [109]. There are four different loads: lighting, HVAC, computing and catering. From a technical perspective, all four loads can contribute to DSR. However, what loads are used for, the regulations affecting their use, and the time constraints of their usage, limit the flexibility that they can offer. Flexing lighting in rooms is not possible as it would affect hotel customers; flexing refrigeration can be done without impacting on users, but health and safety regulations about food conservation make this option unfeasible. HVAC does not share the limitations of the other two loads but whether it can participate in the most profitable forms of DSR depends on the business's acceptance of automatic remote control. 
What electricity is used for, and the social context for those activities impacts on the economic and behavioural barriers discussed in sections 3, 4 and 5. An organisation perception of risk can exemplify this. Organisations may be more or less risk-averse depending on the purpose for which they use energy. Hospitals are often wary of using their generators for DSR as for them, reliability is paramount [119]. For data centres, the issue is one of security and privacy; consequently, their main concern is granting third party access to their equipment [81]. Firms' willingness to consider energy issues is, therefore related to their core business.

\section{Conclusion and policy implications}

The decarbonisation of electricity systems and the associated increase in variable generation requires additional demand side flexibility sources such as DSR. Generally seen as costeffective, DSR has limited technological barriers, but its deployment depends on electricity end-users' ability and willingness to flex their consumption. Yet, research on what influences electricity consumers' decisions about DSR programmes has been limited. Using the UK as a case study, this article has identified and examined barriers that large commercial firms and public sector organisations faced regarding explicit DSR.

We looked at barriers from four different theoretical perspectives. Using an 'orthodox economics' lenses, we found that participating in DSR involves initial capital and transaction costs which studies estimating the economic potential of DSR generally ignore. There are the costs of updating existing equipment and investing in more sophisticated technologies to profit from available DSR opportunities. There are also the costs of finding suitable equipment, of gathering information about DSR options, and of evaluating a firm's ability to flex consumption patterns. Meeting the regulatory requirements of DSR programmes is also costly in terms of time and 'hassle'. Searching and administrative tasks can be done in-house or outsourced to an aggregator, but in either case, firms incur material costs. Firms' perceptions of risk also hinder DSR deployment. Two types of risk are particularly relevant. One is the concern that committing to altering electricity consumption patterns in response to external requests may impact on core business operations. The other type of risk relates to the uncertainty of financial revenues, since these are highly dependent on factors outside of the firm's control, such as the result of auctions in electricity markets.

Social practice theory helped identify several limitations to the uptake of DSR related to the social and material settings, and the temporal rhythms of electricity use. For example, a specific load such as HVAC has considerable technical potential. However, depending on whether the use of HVAC occurs in a hospital or an office setting, this load will be subject to different time constraints and must comply with distinct non-energy regulations. These constraints will, in turn, influence how much flexibility HVAC can provide and which DSR products can be accessed. The profitability of flexing an HVAC load in a hospital or in an office building may thus differ considerably. The existence of hidden costs and the constraints that different sectors face regarding their use of energy suggests that aggregating buildings' flexible loads can provide an inaccurate and optimistic picture of actual flexibility potential.

This study also showed that barriers to participation in DSR exist not only at the level of individual sites and buildings but also at an 'organisational level'. Providing flexibility services can impact on different parts of a business and thus requires the support of a range of stakeholders. Persuading decision-makers whose expertise is not in energy matters of the 
value of DSR is difficult on account of the novelty and complexity of the issue, and the financial risks of trading in electricity markets. Energy not being 'core' to the business - as it is generally the case in commercial and public sector organisations - was also noted as a barrier, as it reduces energy managers' ability to influence other parts of the business. Concepts from behavioural economics such as bounded rationality can also help explain these problems. Decision-makers may lack the knowledge, time, resources or interest to evaluate initial DSR proposals using standard economic methods and therefore make decisions based on rules of thumb instead. During the initial stage of the decision-making process, they may thus overlook the potential financial benefit of participating in DSR. Loss aversion and status quo bias can also help explain the inaction of companies. Flexing consumption and using energy as a profit-making part of the business represent a radical departure from the status quo - having continuous access to power and electricity treated as a service rather than as a revenue-generating asset.

This study has shown that although categories of barriers may be similar for EE and DSR, the specific barriers impacting on each of the two types of demand side management are not the same. For example, although perceptions of risk can hinder both kinds of initiatives, the specific risks affecting each of them is different. The uncertainty of financial returns, for example, is not generally considered a critical risk to EE, but it is one of the most frequently mentioned barriers to DSR. Another example is about the decision-making process in large organisations: both energy initiatives fall within the remit of energy departments and require the support of other parts of the organisation. However, in the case of DSR, the main difficulties faced by energy managers when trying to gain support are the novelty, complexity and inherent financial risks of DSR, which are rarely issues affecting EE initiatives.

\subsection{Limitations of this study}

The three main limitations of this study relate to its geographic focus, the quality of the available empirical data and the use of multiple theoretical lenses. First, the grey literature reviewed in this paper is geographically confined to the UK and (partly) other European countries. At the moment, market opportunities for DSR - in the form of ancillary services, balancing services and wholesale markets - vary significantly across Europe. For example, in Poland, end-users have limited opportunities to engage in DSR compared with Denmark, Finland and the Netherlands. This means that our study does not directly address value questions and issues of how variations in returns associated with DSR may influence decisions taken by industrial and commercial users across different countries. This is something which, in the future, is likely to have significant implications with the spread of market opportunities for demand side flexibility. For instance, in the UK, Distribution Network Operators have recently opened up new opportunities with DSR auctions. The geographic location of a business (and whether they belong to a distribution network) and the value of DSR returns will change also based on the density of end-users in a given region. Similarly, the presence of storage and diminishing returns associated with DSR may turn value into an actual barrier.

Second, with regard to the available empirical data, most surveys and interviews found in the literature were voluntary, involving people who even if not participating in explicit DSR had sufficient interest in the issue to be involved in initiatives relating to DSR. Therefore, their responses relate to higher levels of engagement in DSR than what there is in the sector as a whole. Information about the sectoral composition of participation in explicit DSR is based on estimates and information provided by aggregators, so we do not know with any certainty 
what is the share of participation of the commercial and public sector. We also lack information on which sub-sectors and which type of premises participate most and what is the size of the organisations participating in the UK electricity markets.

Third, the use of multiple conceptual lenses involves some possible overlaps and gaps in the process of identifying barriers. The combination of concepts from orthodox and behavioural economics, organisational studies and social practice theory in this context is unprecedented and brings about significant value to the otherwise theoretically arid territory of DSR. However, there might be overlap about how, for instance, knowledge around DSR is conceptualised and used within an organisation and perceived by individuals when it comes to making investment decisions. In essence, knowledge bridges across behavioural economics and organisational studies. Conversely, there are potential gaps in between the concepts we mobilised in this paper. Social practice theories have been underutilised in this paper (and other research) in relation to how the social rhythms within an organisation -e.g. a hospital [96] - are ordered and shape energy demand and the potential for flexibility.

\subsection{Implications for future research and policy}

This paper has contributed to the existing literature on DSR by identifying barriers to participation in explicit DSR through multiple conceptual lenses. As a result, some of the similarities and differences with EE barriers have been made evident.

The intricacies of the relationship between EE and demand-side flexibility will need to be further explored in relation to a decarbonised electricity grid. Traditionally, EE and DSR have been considered as the two main initiatives under the common umbrella of Demand Side Management. In the late 1970s, utilities started developing both EE and DSR programmes as cost reduction measures. The integration of renewables poses other challenges to the ones which put EE and DSR high on the policy and utility agenda in the 1970s. On the one hand, EE is one of the tools to diminish peak energy demand, hence reducing the need for grid reinforcement. On the other hand, high levels of EE may exacerbate the 'duck' effect - i.e. the phenomenon of high solar generation in the middle of the day when demand is low, and limited renewables generation in the evening when demand is high - particularly regarding low electricity demand. Further research could investigate the potential synergies and conflicts from reducing energy consumption through investment in EE and participating in DSR from a business perspective.

Both in the research and policy arenas energy efficiency has generally been associated with its potential to reduce demand and, consequently, carbon emissions. This means that energy efficiency policies have often been linked to climate change initiatives along with the decarbonisation of generation [149]. The absence of trade-offs and the economic proposition associated with energy efficiency has granted it a 'win-win' position within energy demand research. On the contrary, evidence on decarbonisation has traditionally not been a strong argument for policies in favour of DSR. This is partly due to the very nature of DSR, namely, to shift peak loads, rather than reducing demand per se and partly due to existing data, which tends to be based on commercial users rather than residential ones. In Europe, the recent abandonment of diesel generation for DSR purposes thanks to the Medium Combustion Plant Directive has cleared the field of some of the 'win-lose' arguments around the environmental impacts of DSR. This means that the role of future research is either to enable a like-for-like comparison of the decarbonisation effects of EE and DSR or to suggest combinations of the two based on different end-users, behaviours and social practices. 


\section{Appendix: Details about the literature reviewed}

\section{Table A1}

Empirical sources reviewed in this article (grey literature only)

Sources reviewed Details of interviews, surveys, workshops and meetings

PA Consulting, 2016.

Aggregators - barriers and external impacts. [90]

Ofgem, 2016. Industrial and Commercial DSR in GB: barriers and potential. [19]

Ofgem, 2017. Annual report on the operation of the capacity market in 2016/17 [91]

Charles River Associates, 2017. Assessment of the value of DSR in the Balancing Mechanism - 2017. [77]

Frontier Economics, 2015. Report on the future potential of DSR in GB.[119]

Element Energy, 2012. Demand Side Response in the non-domestic sector. [78]

BEIS, 2016. Building Energy Efficiency Survey Overarching report. [64]

BEIS, 2017. Evaluation of Transitional Arrangements in the Capacity Market [129]

Sustainability First - GB Electricity Demand Project 2012- 2015. [115,126,150]
Literature reviews tested through stakeholder workshops with aggregators, supplier aggregators, Elexon, the SO and Ofgem

Two voluntary online surveys; with over 100 responses from I\&C consumers and over 80 responses from procurers of DSR.

$\mathrm{n} / \mathrm{a}$

Interviews with aggregators, suppliers, Elexon, and National Grid.

Includes informal interviews with market participants

16 telephone interviews with facilities management companies, aggregators and major retailers. Participants were identified via trade association or through direct contact.

Empirical base includes over 3,500 telephone surveys and 214 site surveys, where respondents took part in semistructured interviews. Focus on non-domestic buildings.

64 in-depth interviews with all TA participants and a sample of non-participants; a quantitative survey with 169 non-participant organisations with over $6 \mathrm{GWh}$ yearly. Findings were tested with stakeholders at a workshop.

Interviews and small sample survey; trials and interviews with six small commercial customers. 
House of Commons. Energy and Climate Change Committee, 2016. The energy revolution and future challenges for UK energy and climate change policy.[2]

Energyst, 2015-2018. Annual reports on demand side flexibility $[81,89,125,130]$
Three parliamentary enquiries, of which the relevant one used in this paper is 'Energy Revolution'. It included, witnesses' evidence (12 stakeholders) and published written evidence (118 submissions). Details of evidence in report.

Voluntary survey with businesses (small and large) and public sector organisations, of which around a third provide DSR. Samples vary between 180 and 75 responses.

Interviews with mostly aggregators and DSR providers on different DSR related themes

\section{Documents from Power Responsive: \\ stakeholder-led programme funded by \\ NG to stimulate participation in DSR and other flexible technology}

Power Responsive Demand Side Flexibility Annual reports for 2016, 2017 and 2018 [86]

Power Responsive Steering Group Meetings (13 meetings between January 2017 and October 2018). [131,145]

Snapshots

Flexibility Forums (3 annual forums).
ADE self-reporting survey with aggregators and suppliers -9 responses.

The steering group members include representatives of OFGEM, BEIS, NG, DNOs, electricity suppliers, aggregators and I \&C, including one large retailer (Sainsbury's).

$\mathrm{n} / \mathrm{a}$

Participants include representatives from policy and regulatory organisations, and I\&C customers 'with an interest in DSR'.

DSR trials conducted by network operators and funded by OFGEM's LCN fund

Electricity Norwest - reports based on trials with I\&C customers
Interviews with 180 I\&C customers in 2012 with regard to a new DSR contract offered by the DNO. 
Northern Powergrid Customer-led Network Revolution (CLNR) reports based on trials with I\&C customers 2013 [134]

UK Power Networks - Low Carbon London [132]

\section{Non-UK publications}

E-harbours, 2013. Report on non-technical barriers for smart energy solutions. [123]

SEDC 2015 and 2017. Explicit Demand Response in Europe. Mapping the markets. [37,44]

CAISO, California Independent System Operator, 2009. Demand Response Barriers Study.[28]
The study included interviews with the 3 aggregators and one $\mathrm{I} \& \mathrm{C}$ customer involved in the trials. The trials involved 14 sites.

43 interviews with mostly energy managers (36 interviews) in commercial organizations

The evidence base includes talks with experts in the field (researchers, company energy managers, professional providers of flexible energy solutions) and information the e-harbours expert group gained throughout the implementation of the showcase.

The evidence base includes expert interviews with TSOs, DSOs, retailers, aggregators, regulators and technology providers. National market participants working on DSR reviewed the national reports.

Interviews with 13 entities, including investor-owned utilities, regulatory entities, demand response Providers, consumer advocates, customer representatives, and Energy Service Providers.

Webinar with approximately 50 stakeholders 
Table A2

Publication statistics by location

\begin{tabular}{lll}
\hline Countries/regions & $\begin{array}{l}\text { Number of } \\
\text { publications by } \\
\text { location }\end{array}$ & $\begin{array}{l}\text { Share of number of } \\
\text { publications, by } \\
\text { location }\end{array}$ \\
\hline Europe & 15 & $9 \%$ \\
UK & 67 & $42 \%$ \\
Germany & 16 & $10 \%$ \\
Other European & 16 & $10 \%$ \\
countries & & $11 \%$ \\
USA & 17 & $1 \%$ \\
Other countries & 2 & $1 \%$ \\
Global & 2 & $23 \%$ \\
n/a & 37 &
\end{tabular}

Note: Total is more than 100 percent because some publications include more than one country/region. 
Table A3:

Literature categorised by type, region and year of publication

\begin{tabular}{|c|c|c|c|}
\hline $\begin{array}{l}\text { Ref. } \\
\text { number }\end{array}$ & Type & Location & Publishing year \\
\hline [1] & Report & Europe & 2013 \\
\hline$[2]$ & Report & UK & 2016 \\
\hline$[3]$ & Journal article & $\mathrm{n} / \mathrm{a}$ & 2014 \\
\hline$[4]$ & Report & $\mathrm{UK}$ & 2016 \\
\hline$[5]$ & Journal article & UK & 2008 \\
\hline$[6]$ & Journal article & Europe, UK, Italy, Spain, & 2010 \\
\hline [7] & Report & Global & 2017 \\
\hline$[8]$ & Report & $\mathrm{n} / \mathrm{a}$ & 2018 \\
\hline$[9]$ & Report & Europe & 2016 \\
\hline [10] & $\begin{array}{l}\text { Conference } \\
\text { proceedings }\end{array}$ & $\mathrm{n} / \mathrm{a}$ & 2011 \\
\hline$[11]$ & Journal article & $\mathrm{n} / \mathrm{a}$ & 2015 \\
\hline$[12]$ & Journal article & $\mathrm{n} / \mathrm{a}$ & 2019 \\
\hline$[13]$ & Report & $\mathrm{UK}$ & 2011 \\
\hline$[14]$ & Working paper & USA & 2007 \\
\hline$[15]$ & Journal article & Europe & 2014 \\
\hline$[16]$ & Report & Europe; Belgium & 2014 \\
\hline$[17]$ & $\begin{array}{l}\text { Conference } \\
\text { proceedings }\end{array}$ & USA & 2015 \\
\hline$[18]$ & Journal article & Germany & 2014 \\
\hline$[19]$ & Report & $\mathrm{UK}$ & 2016 \\
\hline$[20]$ & Journal article & $\mathrm{n} / \mathrm{a}$ & 2017 \\
\hline$[21]$ & Journal article & Germany & 2015 \\
\hline$[22]$ & Journal article & $\mathrm{n} / \mathrm{a}$ & 2013 \\
\hline
\end{tabular}


Germany, The Netherlands,

\begin{tabular}{|c|c|c|c|}
\hline & & China, Ireland, UK & \\
\hline [24] & Journal article & $\mathrm{n} / \mathrm{a}$ & 2011 \\
\hline$[25]$ & Journal article & $\mathrm{n} / \mathrm{a}$ & 2016 \\
\hline [27] & Journal article & Switzerland & 2012 \\
\hline$[28]$ & Report & USA & 2009 \\
\hline [29] & Journal article & Germany & 2017 \\
\hline$[30]$ & Book & Europe & 2015 \\
\hline$[31]$ & Journal article & $\mathrm{n} / \mathrm{a}$ & 2014 \\
\hline$[32]$ & Journal article & $\begin{array}{l}\text { North America, South } \\
\text { America, Europe, Oceania, } \\
\text { Asia, Africa }\end{array}$ & 2017 \\
\hline$[33]$ & Journal article & Austria, Germany & 2011 \\
\hline$[34]$ & Journal article & Germany & 2010 \\
\hline$[35]$ & Report & USA & 2006 \\
\hline [36] & Report & Europe & 2019 \\
\hline$[37]$ & Report & Europe & 2015 \\
\hline [38] & Journal article & $\begin{array}{l}\text { France, UK, Sweden, The } \\
\text { Netherlands }\end{array}$ & 2016 \\
\hline [39] & Journal article & $\mathrm{n} / \mathrm{a}$ & 2011 \\
\hline$[40]$ & Journal article & Germany & 2017 \\
\hline$[41]$ & Journal article & USA & 2013 \\
\hline$[42]$ & Journal article & $\mathrm{n} / \mathrm{a}$ & 2014 \\
\hline [43] & $\begin{array}{l}\text { Conference } \\
\text { proceedings }\end{array}$ & UK & 2014 \\
\hline$[44]$ & Report & Europe & 2015 \\
\hline$[45]$ & Report & Europe & 2016 \\
\hline$[46]$ & Journal article & Europe & 2018 \\
\hline
\end{tabular}




\begin{tabular}{|c|c|c|}
\hline [47] & Journal article & Europe \\
\hline$[48]$ & Journal article & UK \\
\hline$[49]$ & Journal article & USA, Europe, China \\
\hline$[50]$ & Journal article & Germany \\
\hline$[51]$ & Journal article & USA \\
\hline$[52]$ & Journal article & USA \\
\hline$[53]$ & Journal article & $\mathrm{n} / \mathrm{a}$ \\
\hline$[54]$ & Journal article & $\mathrm{UK}$ \\
\hline$[55]$ & Journal article & UK \\
\hline$[56]$ & Journal article & Portugal \\
\hline$[57]$ & Journal article & Denmark \\
\hline$[58]$ & Journal article & $\mathrm{n} / \mathrm{a}$ \\
\hline [59] & $\begin{array}{l}\text { Conference } \\
\text { proceedings }\end{array}$ & $\mathrm{n} / \mathrm{a}$ \\
\hline [60] & Position paper & $\mathrm{n} / \mathrm{a}$ \\
\hline$[61]$ & Journal article & Ireland \\
\hline [62] & Journal article & Europe \\
\hline [63] & Report & UK \\
\hline [64] & Report & UK \\
\hline$[65]$ & Journal article & $\mathrm{n} / \mathrm{a}$ \\
\hline [66] & Journal article & The Netherlands \\
\hline [67] & Journal article & Denmark \\
\hline [68] & Journal article & USA \\
\hline [69] & Journal article & UK \\
\hline$[70]$ & Journal article & Germany \\
\hline [71] & Journal article & Sweden \\
\hline
\end{tabular}




\begin{tabular}{|c|c|c|c|}
\hline [72] & Position paper & UK & 2015 \\
\hline [73] & Report & UK & 2017 \\
\hline [74] & Journal article & UK & 2018 \\
\hline [75] & $\begin{array}{l}\text { Generic (written } \\
\text { evidence) }\end{array}$ & UK & 2012 \\
\hline [76] & Journal article & Germany & 2014 \\
\hline [77] & Report & UK & 2017 \\
\hline [78] & Report & UK & 2012 \\
\hline [79] & Website & UK & $\mathrm{n} / \mathrm{a}$ \\
\hline$[80]$ & $\begin{array}{l}\text { Conference } \\
\text { proceedings }\end{array}$ & UK & 2017 \\
\hline [81] & Report & UK & 2017 \\
\hline [82] & Report & UK & 2006 \\
\hline [83] & Journal article & UK & 2009 \\
\hline [84] & $\begin{array}{l}\text { Conference } \\
\text { proceedings }\end{array}$ & UK & 2015 \\
\hline [85] & Generic & UK & 2018 \\
\hline [86] & Report & UK & 2017 \\
\hline [87] & Report & UK & 2016 \\
\hline [88] & Report & UK & 2010 \\
\hline [89] & Report & UK & 2018 \\
\hline [90] & Report & UK & 2016 \\
\hline [91] & Report & UK & 2017 \\
\hline [92] & Journal article & USA and UK & 2017 \\
\hline [93] & Report & UK & 2018 \\
\hline [94] & Journal article & $\mathrm{n} / \mathrm{a}$ & 2018 \\
\hline [95] & Journal article & $\mathrm{n} / \mathrm{a}$ & 2011 \\
\hline
\end{tabular}




\begin{tabular}{|c|c|c|c|}
\hline [96] & Journal article & $\mathrm{n} / \mathrm{a}$ & 2011 \\
\hline [97] & Journal article & USA & 1992 \\
\hline [98] & Book & $\begin{array}{l}\text { Japan, USA, Australia, The } \\
\text { Netherlands, Norway }\end{array}$ & 2007 \\
\hline [99] & Book & Germany, UK & 2004 \\
\hline [100] & Journal article & $\mathrm{n} / \mathrm{a}$ & 2018 \\
\hline [101] & Journal article & Sweden & 2010 \\
\hline$[102]$ & Journal article & $\mathrm{n} / \mathrm{a}$ & 2006 \\
\hline [103] & Journal article & $\mathrm{n} / \mathrm{a}$ & 2015 \\
\hline$[104]$ & Journal article & $\mathrm{n} / \mathrm{a}$ & 2014 \\
\hline$[105]$ & Book & $\mathrm{n} / \mathrm{a}$ & 2014 \\
\hline [106] & Report & UK & 2012 \\
\hline [107] & Journal article & $\mathrm{n} / \mathrm{a}$ & 2014 \\
\hline [108] & Journal article & $\mathrm{n} / \mathrm{a}$ & 2002 \\
\hline [109] & Book chapter & UK & 2012 \\
\hline$[110]$ & Book & $\mathrm{n} / \mathrm{a}$ & 1997 \\
\hline [111] & Journal article & $\mathrm{n} / \mathrm{a}$ & 1974 \\
\hline [112] & Journal article & USA & 1998 \\
\hline [113] & Journal article & UK & 2014 \\
\hline [114] & Journal article & UK & 2010 \\
\hline [115] & Report & UK & 2016 \\
\hline [116] & Report & UK & 2016 \\
\hline [117] & Journal article & Europe & 2014 \\
\hline [118] & Journal article & Germany & 2016 \\
\hline [119] & Report & UK & 2015 \\
\hline$[120]$ & Journal article & Germany & 2011 \\
\hline
\end{tabular}




\begin{tabular}{|c|c|c|c|}
\hline [121] & Journal article & UK and USA & 2018 \\
\hline [122] & Report & UK & 2016 \\
\hline [123] & Report & Germany & 2013 \\
\hline [124] & Meeting notes & UK & 2018 \\
\hline [125] & Report & UK & 2015 \\
\hline [127] & Meeting notes & UK & 2018 \\
\hline [126] & Report & UK & 2012 \\
\hline [128] & Journal article & Europe & 2017 \\
\hline [129] & Report & UK & 2017 \\
\hline [130] & Report & UK & 2016 \\
\hline [131] & Meeting notes & UK & 2018 \\
\hline [132] & Report & UK & 2014 \\
\hline [133] & Journal article & UK & 2015 \\
\hline [134] & Report & $\mathrm{UK}$ & 2013 \\
\hline [135] & Journal article & USA & 2001 \\
\hline [136] & Journal article & Germany & 2008 \\
\hline [137] & Report & UK & 2017 \\
\hline [138] & Report & $\mathrm{UK}$ & 2017 \\
\hline [139] & Report & $\mathrm{UK}$ & 2016 \\
\hline [140] & Magazine article & USA & 2010 \\
\hline [141] & Journal article & Germany & 2008 \\
\hline [142] & Journal article & $\mathrm{n} / \mathrm{a}$ & 1979 \\
\hline [143] & Book chapter & $\mathrm{n} / \mathrm{a}$ & 2014 \\
\hline [144] & Journal article & $\mathrm{n} / \mathrm{a}$ & 1991 \\
\hline [145] & Meeting notes & $\mathrm{UK}$ & 2017 \\
\hline [146] & Journal article & $\mathrm{n} / \mathrm{a}$ & 2005 \\
\hline
\end{tabular}




$\begin{array}{llll}{[147]} & \text { Journal article } & \text { UK } & 2011 \\ {[148]} & \text { Book } & \text { UK and France } & 2018 \\ {[149]} & \text { Journal article } & \text { n/a } & 2017 \\ {[150]} & \text { Report } & \text { UK } & 2014 \\ {[151]} & \text { Journal article } & \text { Germany } & 2017 \\ {[152]} & \text { Report } & \text { Europe } & 2018 \\ {[153]} & \text { Journal article } & \text { USA } & 2011 \\ {[154]} & \text { Website } & \text { Europe } & \text { n/a } \\ {[155]} & \text { Report } & \text { Global } & 2017 \\ {[156]} & \text { Journal article } & \text { n/a } & 2014 \\ {[157]} & \text { Report } & \text { UK } & 2018 \\ {[158]} & \text { Journal article } & \text { n/a } & 2019 \\ {[159]} & \text { Report } & \text { UK } & 2012\end{array}$

Note: details of location are provided when the publication examines, reviews or includes a significant amount of data about a specific country or region.

\section{Bibliography}

[1] European Commission, Incorporating demand side flexibility, in particular demand response, in electricity markets. Accompanying the document "Communication from the Commission: Delivering the internal electricity market and making the most of public intervention," 2013.

[2] House of Commons - Energy and Climate Change, The energy revolution and future challenges for UK energy and climate change policy, 2016.

https://www.publications.parliament.uk/pa/cm201617/cmselect/cmenergy/705/705.pdf

[3] N. O'Connell, P. Pinson, H. Madsen, M. O'malley, Benefits and challenges of electrical demand response: A critical review, Renew. Sustain. Energy Rev. 39 (2014) 686-699. doi:10.1016/j.rser.2014.07.098.

[4] Carbon Trust and Imperial College, An analysis of electricity system flexibility for Great Britain, 2016.

https://www.gov.uk/government/uploads/system/uploads/attachment_data/file/568982/ An_analysis_of_electricity_flexibility_for_Great_Britain.pdf.

[5] G. Strbac, Demand side management: Benefits and challenges, Energy Policy. 36 
(2008) 4419-4426. doi:10.1016/j.enpol.2008.09.030.

[6] J. Torriti, M.G. Hassan, M. Leach, Demand response experience in Europe : Policies , programmes and implementation, Energy. 35 (2010) 1575-1583.

doi:10.1016/j.energy.2009.05.021.

[7] IEA, World Energy Outlook 2017, 2017.

[8] IEA, Commentary: The clean energy transition requires action on electricity demand, (2018) 1-4. http://www.iea.org/newsroom/news/2018/january/commentary-the-cleanenergy-transition-requires-action-on-electricity-demand.html (accessed August 11, 2018).

[9] COWI et al, Impact Assessment Study on Downstream Flexibility, Demand Response \& Smart Metering. European Commission, DG Enegy. Prepared by COWI in cooperation with Ecofys, Thema Consulting Group and Vito Energy Ville., 2016. https://ec.europa.eu/energy/sites/ener/files/documents/demand_response_ia_study_fina 1_report_12-08-2016.pdf.

[10] V.S.K.M.K.M. Balijepalli, V. Pradhan, S.A. Khaparde, R.M. Shereef, Review of Demand Response under Smart Grid Paradigm AM I AT C, in: 2011 IEEE PES Int. Conf. Innov. Smart Grid Technol. ISGT India 2011, IEEE, 2011: pp. 236-243. doi:10.1109/ISET-India.2011.6145388.

[11] S. Nolan, M. O'Malley, Challenges and barriers to demand response deployment and evaluation, Appl. Energy. 152 (2015) 1-10. doi:10.1016/j.apenergy.2015.04.083.

[12] A.R. Jordehi, Optimisation of demand response in electric power systems, a review, Renew. Sustain. Energy Rev. 103 (2019) 308-319. doi:10.1016/j.rser.2018.12.054.

[13] DECC, Smart Meter roll-out for the non-domestic sector (GB). Impact Assessment. Final, 2012.

[14] C. Goldman, N. Hopper, R. Bharvirkar, B. Neenan, P. Cappers, Estimating LargeCustomer Demand Response Market Potential : Integrating Price and Customer Behavior Approaches Used to Study DR Market Potential, Lawrence Berkeley Natl. Lab. (2007).

[15] H.C. Gils, Assessment of the theoretical demand response potential in Europe, Energy. 67 (2014) 1-18. doi:10.1016/j.energy.2014.02.019.

[16] Sia Partners, Demand Response : A study of its potential in Europe, (2015).

[17] H. Hao, T. Middelkoop, P. Barooah, S. Meyn, How demand response from commercial buildings will provide the regulation needs of the grid, in: Fiftieth Annu. Allert. Conf., IEEE, 2012: pp. 1908-1913. doi:10.1109/Allerton.2012.6483455.

[18] E. Koliou, C. Eid, J.P. Chaves-ávila, R.A. Hakvoort, Demand response in liberalized electricity markets : Analysis of aggregated load participation in the German balancing mechanism, Energy. 71 (2014) 245-254. doi:10.1016/j.energy.2014.04.067. 
[19] Ofgem, Industrial and Commercial demand-side response in GB: barriers and potential. Analysis of Ofgem's surveys on demand-side response (DSR) provision by large Industrial and Commercial (I\&C) consumers, 2016.

https://www.ofgem.gov.uk/system/files/docs/2016/10/industrial_and_commercial_dem and-side_response_in_gb_barriers_and_potential.pdf.

[20] N. Good, K.A. Ellis, P. Mancarella, Review and classification of barriers and enablers of demand response in the smart grid, Renew. Sustain. Energy Rev. 72 (2017) 57-72. doi:10.1016/j.rser.2017.01.043.

[21] M. Olsthoorn, J. Schleich, M. Klobasa, Barriers to electricity load shift in companies: A survey-based exploration of the end-user perspective, Energy Policy. 76 (2015) 3242. doi:10.1016/j.enpol.2014.11.015.

[22] E. Cagno, E. Worrell, A. Trianni, G. Pugliese, A novel approach for barriers to industrial energy efficiency, Renew. Sustain. Energy Rev. 19 (2013) 290-308. doi:10.1016/j.rser.2012.11.007.

[23] S. Sorrell, A. Mallett, S. Nye, Barriers to industrial energy efficiency: a literature review. United Nations Industrial Development, Working Paper 10/2011, 2011. doi:10.1016/j.rser.2015.03.002.

[24] C. Cooremans, Make it strategic! Financial investment logic is not enough, Energy Effic. 4 (2011) 473-492. doi:10.1007/s12053-011-9125-7.

[25] S.C. Staddon, C. Cycil, M. Goulden, C. Leygue, A. Spence, Intervening to change behaviour and save energy in the workplace: A systematic review of available evidence, Energy Res. Soc. Sci. 17 (2016) 30-51. doi:10.1016/j.erss.2016.03.027.

[26] S.J. DeCanio, W.E. Watkins, Investment in Energy Efficiency: Do the characteristics of the firms matter, Rev. Econ. Stat. 80 (2001) 95-107.

[27] C. Cooremans, Investment in energy efficiency: Do the characteristics of investments matter?, Energy Effic. 5 (2012) 497-518. doi:10.1007/s12053-012-9154-x.

[28] CAISO, California Independent System Operator, Demand Response Barriers Study (per FERC Order 179). Prepared by: Freeman, Sullivan \& Co. and Energy and Environmental Economics, Inc., 2009.

[29] C. Kuzemko, C. Mitchell, M. Lockwood, R. Hoggett, Policies, politics and demand side innovations: The untold story of Germany's energy transition, Energy Res. Soc. Sci. 28 (2017) 58-67. doi:10.1016/j.erss.2017.03.013.

[30] J. Torriti, Peak Energy Demand and Demand Side Response, Routledge, London and New York, 2015. doi:10.4324/9781315781099.

[31] L. Gelazanskas, K.A.A. Gamage, Demand side management in smart grid: A review and proposals for future direction, Sustain. Cities Soc. 11 (2014) 22-30. doi:10.1016/j.scs.2013.11.001.

[32] N.G. Paterakis, O. Erdinç, J.P.S. Catalão, An overview of Demand Response: Key- 
elements and international experience, Renew. Sustain. Energy Rev. 69 (2017) 871891. doi:10.1016/j.rser.2016.11.167.

[33] P. Palensky, D. Dietrich, Demand side management: Demand response, intelligent energy systems, and smart loads, IEEE Trans. Ind. Informatics. 7 (2011) 381-388. doi:10.1109/TII.2011.2158841.

[34] M. Paulus, F. Borggrefe, The potential of demand-side management in energyintensive industries for electricity markets in Germany, Appl. Energy. 88 (2011) 432441. doi:10.1016/j.apenergy.2010.03.017.

[35] DOE - US Department of Energy, Benefits of demand response in electricity markets and recommendations for achieving them; A report to the United States Congress Pursuant to Section 1252 of the Energy Policy Act of 2005, 2006. https://eetd.lbl.gov/sites/all/files/publications/report-lbnl-1252d.pdf (accessed August $25,2018)$.

[36] European Smart Grids Task Force Expert Group 3, Demand Side Flexibility Perceived barriers and proposed recommendations, 2019.

[37] SEDC - Smart Energy Demand Coalition, Explicit Demand Response in Europe, Mapping the markets 2017, 2017. http://www.smarten.eu/wpcontent/uploads/2017/04/SEDC-Explicit-Demand-Response-in-Europe-Mapping-theMarkets-2017.pdf.

[38] C. Eid, E. Koliou, M. Valles, J. Reneses, R. Hakvoort, Time-based pricing and electricity demand response: Existing barriers and next steps, Util. Policy. 40 (2016) 15-25. doi:10.1016/j.jup.2016.04.001.

[39] J.H. Kim, A. Shcherbakova, Common failures of demand response, Energy. 36 (2011) 873-880. doi:10.1016/j.energy.2010.12.027.

[40] A. Aryandoust, J. Lilliestam, The potential and usefulness of demand response to provide electricity system services, Appl. Energy. 204 (2017). doi:10.1016/j.apenergy.2017.07.034.

[41] P. Cappers, J. MacDonald, C. Goldman, O. Ma, An assessment of market and policy barriers for demand response providing ancillary services in U.S. electricity markets, Energy Policy. 62 (2013) 1031-1039. doi:10.1016/j.enpol.2013.08.003.

[42] B. Biegel, M. Westenholz, L.H. Hansen, J. Stoustrup, P. Andersen, S. Harbo, Integration of flexible consumers in the ancillary service markets, Energy. 67 (2014) 479-489. doi:10.1016/j.energy.2014.01.073.

[43] P. Gruenewald, J. Torriti, Any response? How demand response could be enhanced based on early UK experience, in: Int. Conf. Eur. Energy Mark. EEM, 2014. doi:10.1109/EEM.2014.6861247.

[44] SEDC - Smart Energy Demand Coalition, Mapping Demand Response in Europe Today 2015, 2015. http://www.febeliec.be/web/infosession strategic demand reserve 16_5_2014/1011306087/list1187970122/f1.html\%5Cnhttp://sedc-coalition.eu/wp- 
content/uploads/2014/04/SEDC-Mapping_DR_In_Europe-2014-04111.pdf (accessed May 14, 2018).

[45] B. Bertoldi, Paolo; Zancanella, Paolo; Boza-Kiss, Demand Response status in EU Member States, European Commission -JRC Science for Policy Report., 2016. doi:10.2790/962868.

[46] N. Labanca, P. Bertoldi, Beyond energy efficiency and individual behaviours: policy insights from social practice theories, Energy Policy. 115 (2018) 494-502. doi:10.1016/j.enpol.2018.01.027.

[47] O. Borne, K. Korte, Y. Perez, M. Petit, A. Purkus, Barriers to entry in frequencyregulation services markets : Review of the status quo and options for improvements, Renew. Sustain. Energy Rev. 81 (2018) 605-614. doi:10.1016/j.rser.2017.08.052.

[48] P. Bradley, M. Leach, J. Torriti, A review of the costs and benefits of demand response for electricity in the UK, Energy Policy. 52 (2011) 312-327. doi:10.1016/j.enpol.2012.09.039.

[49] J. Aghaei, M.I. Alizadeh, Demand response in smart electricity grids equipped with renewable energy sources: A review, Renew. Sustain. Energy Rev. 18 (2013) 64-72. doi:10.1016/j.rser.2012.09.019.

[50] M. Steurer, M. Miller, U. Fahl, K. Hufendiek, Enabling demand side integrationassessment of appropriate information and communication technology infrastructures, their costs and possible impacts on the electricity system, in: SmartER Eur. E-World Energy Water 2015, 2015. https://www.ier.unistuttgart.de/publikationen/veroeffentlichungen/downloads/20150121_SmartER_Europ e_Steurer_Miller_et_al.pdf (accessed August 25, 2018).

[51] X. Yan, Y. Ozturk, Z. Hu, Y. Song, A review on price-driven residential demand response, Renew. Sustain. Energy Rev. 96 (2018). doi:10.1016/j.rser.2018.08.003.

[52] H. Allcott, Rethinking real-time electricity pricing, Resour. Energy Econ. 33 (2011) 820-842. doi:10.1016/j.reseneeco.2011.06.003.

[53] M.L. Nicolson, M.J. Fell, G.M. Huebner, Consumer demand for time of use electricity tariffs: A systematized review of the empirical evidence, Renew. Sustain. Energy Rev. 97 (2018) 276-289. doi:10.1016/j.rser.2018.08.040.

[54] M.J. Fell, D. Shipworth, G.M. Huebner, C.A. Elwell, Public acceptability of domestic demand-side response in Great Britain: The role of automation and direct load control, Energy Res. Soc. Sci. 9 (2015) 72-84. doi:10.1016/j.erss.2015.08.023.

[55] P. Grunewald, M. Diakonova, Flexibility, dynamism and diversity in energy supply and demand: A critical review, Energy Res. Soc. Sci. 38 (2018) 58-66. doi:10.1016/j.erss.2018.01.014.

[56] M.A.R. Lopes, C. Henggeler Antunes, K.B. Janda, P. Peixoto, N. Martins, The potential of energy behaviours in a smart(er) grid: Policy implications from a Portuguese exploratory study, Energy Policy. 90 (2016). 
doi:10.1016/j.enpol.2015.12.014.

[57] F. Friis, T. Haunstrup Christensen, The challenge of time shifting energy demand practices: Insights from Denmark, Energy Res. Soc. Sci. (2016).

doi:10.1016/j.erss.2016.05.017.

[58] E. McKenna, S. Higginson, P. Grunewald, S.J. Darby, Simulating residential demand response: Improving socio-technical assumptions in activity-based models of energy demand, Energy Effic. 11 (2018) 1583-1597. doi:10.1007/s12053-017-9525-4.

[59] P. Grunewald, Flexibility in supply and demand, in: DEMAND Cent. Conf., 2016: pp. 1-18. doi:http://dx.doi.org/.

[60] B. Parrish, P. Heptonstall, R. Gross, Hubnet Position Paper 11: How much can we really expect from smart consumers?, 2016.

http://www.hubnet.org.uk/position_papers.

[61] P. Finn, C. Fitzpatrick, Demand side management of industrial electricity consumption: Promoting the use of renewable energy through real-time pricing, Appl. Energy. 113 (2014) 11-21. doi:10.1016/j.apenergy.2013.07.003.

[62] P. Siano, Demand response and smart grids - A survey, Renew. Sustain. Energy Rev. 30 (2014) 461-478. doi:10.1016/j.rser.2013.10.022.

[63] BEIS, Chapter 5: Electricity, Digest of UK Energy Statistics (DUKES), 2017. https://www.gov.uk/government/uploads/system/uploads/attachment_data/file/633779/ Chapter_5.pdf.

[64] BEIS, Building Energy Efficiency Survey, 2014 - 15: Overarching Report, 2016. https://assets.publishing.service.gov.uk/government/uploads/system/uploads/attachme nt_data/file/565748/BEES_overarching_report_FINAL.pdf (accessed May 16, 2018).

[65] D. Christantoni, S. Oxizidis, D. Flynn, D.P. Finn, Implementation of demand response strategies in a multi-purpose commercial building using a whole-building simulation model approach, Energy Build. 131 (2016) 76-86. doi:10.1016/j.enbuild.2016.09.017.

[66] I. Georgievski, V. Degeler, G.A. Pagani, T.A. Nguyen, A. Lazovik, M. Aiello, Optimizing energy costs for offices connected to the smart grid, IEEE Trans. Smart Grid. 3 (2012) 2273-2285. doi:10.1109/TSG.2012.2218666.

[67] S. Rotger-Griful, R.H. Jacobsen, R.S. Brewer, M.K. Rasmussen, Green lift: Exploring the demand response potential of elevators in Danish buildings, Energy Res. Soc. Sci. 32 (2017) 55-64. doi:10.1016/j.erss.2017.04.011.

[68] B. Kirby, J. Kueck, T. Laughner, K. Morris, Spinning Reserve from Hotel Load Response, Electr. J. 21 (2008) 59-66. doi:10.1016/j.tej.2008.11.004.

[69] P. Grünewald, J. Torriti, Demand response from the non-domestic sector: Early UK experiences and future opportunities, Energy Policy. 61 (2013) 423-429.

doi:10.1016/j.enpol.2013.06.051. 
[70] K. Wohlfarth, M. Klobasa, A. Eßer, Setting course for demand response in the service sector, Energy Effic. (2018) 1-15. doi:10.1007/s12053-018-9728-3.

[71] M.B. Bulut, M. Odlare, P. Stigson, F. Wallin, I. Vassileva, Active buildings in smart grids - Exploring the views of the Swedish energy and buildings sectors, Energy Build. 117 (2016) 185-198. doi:10.1016/j.enbuild.2016.02.017.

[72] Ofgem, Making the electricity system more flexible and delivering the benefits for consumers, Position paper., 2015.

[73] BEIS and Ofgem, Upgrading Our Energy System Smart Systems and Flexibility Plan, 2017.

https://www.gov.uk/government/uploads/system/uploads/attachment_data/file/633442/ upgrading-our-energy-system-july-2017.pdf (accessed September 26, 2017).

[74] M. Goulden, A. Spence, J. Wardman, C. Leygue, Differentiating 'the user' in DSR: Developing demand side response in advanced economies, Energy Policy. 122 (2018) 176-185. doi:10.1016/j.enpol.2018.07.013.

[75] National Grid, Written evidence submitted by the nationalgrid REV0118, (2016) 1-2. http://data.parliament.uk/writtenevidence/committeeevidence.svc/evidencedocument/e nergy-and-climate-change-committee/energy-revolution/written/32989.html.

[76] A. Gruber, F. Biedermann, S. Von Roon, The Merit Order of Demand Response in Industry, in: 9th Conf. Energy Econ. Technol., 2014: pp. 1-17. www.ffegmbh.de (accessed August 25, 2018).

[77] Ofgem, Charles River Associates, An assessment of the economic value of demandside participation in the Balancing Mechanism and an evaluation of options to improve access - prepared for Ofgem, 2017. www.crai.com. (accessed May 15, 2018).

[78] Element Energy, Demand side response in the non-domestic sector, Final report for Ofgem, in association with De Montford University, Leicester, UK, 2012.

[79] Elexon, What are the Profile Classes, (n.d.). https://www.elexon.co.uk/knowledgebase/profile-classes/ (accessed May 9, 2019).

[80] M. Curtis, Demand side response aggregators: How they decide customer suitability, in: Int. Conf. Eur. Energy Mark. EEM, IEEE, 2017: pp. 1-6. doi:10.1109/EEM.2017.7981909.

[81] Energyst, Demand Side Response: Shifting the balance of power, 2017 Report, 2017.

[82] DEFRA, Consultation on measures to reduce carbon emissions in the large non-energy intensive business and public sectors, 2006.

[83] M. Grubb, A.B. Haney, J. Wilde, Plugging the gap in energy efficiency policies: the emergence of the UK carbon reduction commitment, Eur. Rev. Energy .... 3 (2009) 131. http://www.eeinstitute.org/european-review-of-energy-market/EREM_8_Article_Grubb__Brophy_Haney_-amp__Wilde.pdf. 
[84] M. Curtis, Barriers to Uptake of Demand Side Response in Medium Sized Businesses, in: Energy Secur. Technol. Sustain. Challenges Across Globe, 2015.

[85] ADE, Demand Side Response Code of Conduct, Version V.1, (2018). https://www.theade.co.uk/assets/docs/about/DSR_Code_of_Conduct.pdf (accessed December 15, 2018).

[86] National Grid, Power responsive - Demand Side Flexibility Annual Report 2017, 2017. http://powerresponsive.com/wp-content/uploads/2018/02/Power-ResponsiveAnnual-Report-2017.pdf.

[87] ADE, Bringing Energy Together, 2016. https://www.theade.co.uk/assets/docs/resources/Flexibility_on_demand_full_report.pd $\mathrm{f}$ (accessed June 14, 2018).

[88] Ofgem, Demand side response: A Discussion Paper, London, 2010. doi:10.1038/npre.2011.6287.2.

[89] Energyst, Demand Side Response, Aligning risk and reward, 2018 Report., 2018.

[90] PA Consulting Group, Aggregators -Barriers and External Impacts, 2016. https://www.ofgem.gov.uk/system/files/docs/2016/07/aggregators_barriers_and_extern al_impacts_a_report_by_pa_consulting_0.pdf.

[91] Ofgem, Annual Report on the Operation of the Capacity Market in 2016/17, 2017.

[92] Y. Liu, Demand response and energy efficiency in the capacity resource procurement: Case studies of forward capacity markets in ISO New England, PJM and Great Britain, Energy Policy. 100 (2017) 271-282. doi:10.1016/j.enpol.2016.10.029.

[93] National Grid, Non-BM Balancing Services Volumes and Expenditure, 2018. https://www.nationalgrid.com/sites/default/files/documents/Non-BM Balancing Services and Volumes 2015-16.pdf (accessed July 31, 2018).

[94] B.K. Sovacool, J. Axsen, S. Sorrell, Promoting novelty, rigor, and style in energy social science: Towards codes of practice for appropriate methods and research design, Energy Res. Soc. Sci. (2018) 1-31. doi:https://doi.org/10.1016/j.erss.2018.07.007.

[95] S. McNamara, M. Grubb, The psychological underpinnings of the consumer role in energy demand and carbon abatement, 2011.

https://www.repository.cam.ac.uk/handle/1810/242030\%5Cnhttp://www.eprg.group.ca m.ac.uk/wp-content/uploads/2014/01/1110-text1.pdf.

[96] M. Pollitt, I. Shaorshadze, The Role of Behavioural Economics in Energy and Climate Policy, 2011.

[97] P.B. Cebon, 'Twixt cup and lip organizational behaviour, technical prediction and conservation practice, Energy Policy. 20 (1992) 802-814. doi:10.1016/03014215(92)90117-K.

[98] IEA, Mind the Gap, Quantifying Principal-Agent Problems in Energy Efficiency, 
2007. http://www.iea.org/Textbase/about/copyright.asp (accessed November 8, 2018).

[99] S. Sorrell, E. O'Malley, J. Schleich, S. Scott, The economics of energy efficiency, Edward Elgar, 2004. doi:10.1002/eet.383.

[100] F.W. Geels, T. Schwanen, S. Sorrell, K. Jenkins, B.K. Sovacool, Reducing energy demand through low carbon innovation: A sociotechnical transitions perspective and thirteen research debates, Energy Res. Soc. Sci. 40 (2018) 23-35.

doi:10.1016/j.erss.2017.11.003.

[101] J. Palm, P. Thollander, An interdisciplinary perspective on industrial energy efficiency, Appl. Energy. 87 (2010) 3255-3261. doi:10.1016/j.apenergy.2010.04.019.

[102] S. Guy, Designing urban knowledge: Competing perspectives on energy and buildings, Environ. Plan. C Gov. Policy. 24 (2006) 645-659. doi:10.1068/c0607j.

[103] S. Sorrell, Reducing energy demand: A review of issues, challenges and approaches, Renew. Sustain. Energy Rev. 47 (2015) 74-82. doi:10.1016/j.rser.2015.03.002.

[104] L. Lutzenhiser, Through the energy efficiency looking glass, Energy Res. Soc. Sci. 1 (2014) 141-151. doi:10.1016/j.erss.2014.03.011.

[105] M. Grubb, J.C. Hourcade, K. Neuhoff, Planetary Economics: The Three Domains of Sustainable Energy Development: Energy, Climate Change and the Three Domains of Sustainable Development, Routledge, 2014.

https://books.google.co.uk/books?id=QxhgAwAAQBAJ\&printsec $=$ frontcover\&dq=pla netary+economics\&hl=en\&sa=X\&ved=0ahUKEwiNyMKA35jWAhWbHsAKHauMB OQQ6AEIJjAA\#v=onepage \&q=planetary economics\&f=false $($ accessed September 9 , 2017).

[106] N. Banks, Z. Redgrove, What are the Factors Influencing Energy Behaviours and Decision-Making in the Non-Domestic Sector? A Rapid Evidence Assessment, 2012. doi:http://dx.doi.org/.

[107] E. Shove, G. Walker, What Is Energy For? Social Practice and Energy Demand, Cult. Soc. 31 (2014) 41-58. doi:10.1177/0263276414536746.

[108] A. Reckwitz, Toward a theory of social practices: A development in culturalist theorizing, Eur. J. Soc. Theory. 5 (2002) 243-263. doi:10.1177/13684310222225432.

[109] M. Curtis, J. Torriti, S.T. Smith, Demand side flexibility and responsiveness: Moving demand in time through technology, in: Demanding Energy Space, Time Chang., 2017: pp. 283-312. doi:10.1007/978-3-319-61991-0_13.

[110] H.A. Simon, Models of Bounded Rationality - Section IV.3 Bounded Rationality, Cambridge, Mass: MIT PRess, 1997.

[111] A. Tversky, D. Kahneman, Judgment under Uncertainty : Heuristics and Biases, Science (80-. ). 185 (1974) 1124-1131. doi:10.1126/science.185.4157.1124.

[112] S.J. DeCanio, The efficiency paradox: bureaucratic and organizational barriers to 
profitable energy-saving investments, Energy Policy. 26 (1998) 441-454.

doi:10.1016/S0301-4215(97)00152-3.

[113] G. Walker, The dynamics of energy demand: Change, rhythm and synchronicity, Energy Res. Soc. Sci. 1 (2014) 49-55. doi:10.1016/j.erss.2014.03.012.

[114] E. Shove, Beyond the ABC: Climate change policy and theories of social change, Environ. Plan. A. 42 (2010) 1273-1285. doi:10.1068/a42282.

[115] J. Duddeney, C. and Ward, Innovate UK / Tempus Project - The Global Electricity Revolution for Consumers Interim Paper by Sustainability Plus, 2016.

[116] Carbon Trust and Imperial College, Can storage help reduce the cost of a future UK electricity system ?, 2016.

[117] J. Torriti, P. and Grunewald, Demand Side Response: Patterns in Europe and Future Policy Perspectives under Capacity Mechanisms, Econ. Energy Environ. Policy. 3 (2014) 87-105. doi:10.5547/2160-5890.3.1.jtor.

[118] H.C. Gils, Economic potential for future demand response in Germany - Modeling approach and case study, Appl. Energy. 162 (2016) 401-415.

doi:10.1016/j.apenergy.2015.10.083.

[119] Frontier Economics, Future potential for DSR in GB, a report prepared for DECC by Frontier Economics with support from LCP and Sustainability First, 2015.

[120] A. Grein, M. Pehnt, Load management for refrigeration systems: Potentials and barriers, Energy Policy. 39 (2011) 5598-5608. doi:10.1016/j.enpol.2011.04.040.

[121] M. Curtis, J. Torriti, S.T. Smith, A comparative analysis of building energy estimation methods in the context of demand response, Energy Build. 174 (2018) 13-25. doi:10.1016/j.enbuild.2018.06.004.

[122] E. Proffitt, Profiting from Demand Side Response The Major Energy Users' Council in association with National Grid, (2016). http://powerresponsive.com/wpcontent/uploads/pdf/ng_meuc-dsr-book.pdf (accessed October 3, 2017).

[123] E-harbours, Report on non-technical barriers for smart energy solutions. Report by the e-harbours expert group on Smart Energy Networks., 2013.

[124] PRSG - snapshot 2018 Feb, Power Responsive Snapshot: Sources of demand side flexibility from asset and provider perspectives, (2018). http://powerresponsive.com/wp-content/uploads/2018/02/Power-ResponsiveSnapshot-Asset-Led-Perspectives-on-DSF.pdf (accessed June 18, 2018).

[125] Energyst, Demand Side Response: Bringing businesses into balancing, 2015 report, 2015. http://theenergyst.com/wp-content/uploads/2015/08/Demand-Side-Responsereport-2015.pdf (accessed May 17, 2018).

[126] Sustainability First (Serena Hesmondhalgh), Sustainability First, GB Electricity Demand - realising the resource; Paper 2 - GB Electricity Demand - 2010 and 2025. 
Initial Brattle Electricity Demand-Side model - Scope for demand reduction and flexible response., 2012.

[127] PRSG - snapshot 2018 July, Power Resonsive. Snapshot: emerging opportunities from location- based demand side flexibility (DSF) and electric vehicles., (2018).

http://powerresponsive.com/wp-content/uploads/2018/07/Power-Responsive-snapshoton-place-based-flexibility-and-electric-vehicles-5-July-2018.pdf (accessed January 7, 2019).

[128] A.M. Carreiro, H.M. Jorge, C.H. Antunes, Energy management systems aggregators: A literature survey, Renew. Sustain. Energy Rev. 73 (2017) 1160-1172. doi:10.1016/j.rser.2017.01.179.

[129] BEIS, Evaluation of the Transitional Arrangements: Phase 1 - Main Report, 2017. https://www.gov.uk/government/publications/evaluation-of-the-transitionalarrangements-phase- 1 .

[130] Energyst, Demand Side Response: Turning inertia into inertia, 2016 Report, 2016.

[131] PRSG 10, Power Responsive Steering Group Note of Tenth Meeting, January 2018, (2018) 1-7.

[132] M. Woolf, T. Ustinova, E. Ortega, E. O’Brien, P. Djapic, G. Strbac, Distributed generation \& demand side response services for smart distribution network, Report A7 for the "Low Carbon London" LCNF project: Imperial College London, 2014, 2014.

[133] M. Goulden, A. Spence, Caught in the middle: The role of the Facilities Manager in organisational energy use, Energy Policy. 85 (2015) 280-287.

doi:10.1016/j.enpol.2015.06.014.

[134] Northern Powergrid, CLNR - Initial Report on Industrial and Commercial Demand Side Response Trials, 2013.

[135] M.A. Brown, Market failures and barriers as a basis for clean energy policies, Energy Policy. 29 (2001) 1197-1207. doi:10.1016/S0301-4215(01)00067-2.

[136] J. Schleich, E. Gruber, Beyond case studies: Barriers to energy efficiency in commerce and the services sector, Energy Econ. 30 (2008) 449-464.

doi:10.1016/j.eneco.2006.08.004.

[137] A. Spence, E. Costanza, N. Banks, M. Goulden, B. Bedwell, C. Leygue, R. Yang, D. Mcauley, C-tech : Creating the Energy for Change, 2017.

[138] Committee on Climate Change, Energy Prices and Bills - impact of meeting carbon budgets, 2017.

[139] P. Mallaburn, A new approach to non-domestic energy efficiency policy, a report for the Committee on Climate Change, 2016. https://www.theccc.org.uk/wpcontent/uploads/2016/10/A-new-approach-to-non-domestic-energy-efficiency.pdf (accessed September 15, 2017). 
[140] H. Allcott, S. Mullainathan, Behaviour and Energy Policy, Science (80-. ). 327 (2010) 1204-1205.

[141] J. Schleich, Barriers to energy efficiency: A comparison across the German commercial and services sector, Ecol. Econ. 68 (2009) 2150-2159.

doi:10.1016/j.ecolecon.2009.02.008.

[142] D. Kahneman, A. Tversky, Prospect Theory: An Analysis of Decision under Risk, Econometrica. 47 (1979) 263-292. http://www.jstor.org/stable/1914185 (accessed May 28, 2018).

[143] M. Grubb, J. Hourcade, N. K, Chapter 4: Why so wasteful, in: Planet. Econ. Energy, Clim. Chang. Three Domains Sustain. Dev., 2014: p. page 147.

[144] D. Kahneman, J.L. Knetsch, R.H. Thaler, Anomalies: The Endowment Effect, Loss Aversion, and Status Quo Bias, J. Econ. Perspect. 5 (1991) 193-206. doi:10.1257/jep.5.1.193.

[145] PRSG 06, Power Responsive Steering Group Note of Sixth Meeting, January 2017, (n.d.) $1-6$.

[146] A. Warde, Consumption and theories of practice, J. Consum. Cult. 5 (2005) 131-153. doi:10.1177/1469540505053090.

[147] T. Hargreaves, Practice-ing behaviour change: Applying social practice theory to proenvironmental behaviour change., J. Consum. Cult. 11 (2011) 79-99. doi:10.1177/1469540510390500.

[148] A. Hui, R. Day, G. Walker, A. Hui, G. Walker, R. Day, Demanding energy: An introduction, in: Demanding Energy, 2018: pp. 1-26. doi:10.1007/978-3-319-619910_1.

[149] E. Shove, What is wrong with energy efficiency?, Build. Res. Inf. (2017) 1-11. doi:10.1080/09613218.2017.1361746.

[150] J. Dudeney, C, Owen, G, and Ward, GB Electricity Demand Project - realising the resource. Paper 13 Realising the Resource: GB Electricity Demand Project Overview, by Sustainability First, 2014.

[151] M. Olsthoorn, J. Schleich, S. Hirzel, Adoption of Energy Efficiency Measures for Non-residential Buildings: Technological and Organizational Heterogeneity in the Trade, Commerce and Services Sector, Ecol. Econ. 136 (2017) 240-254. doi:10.1016/j.ecolecon.2017.02.022.

[152] Bertoldi P, Diluiso F, Castellazzi L, Energy Consumption and Energy Efficiency Trends in the EU-28 2000-2015. European Commission, JRC Science for Policy Report., 2018. doi:10.2760/6684.

[153] H. Allcott, Rethinking Real Time Electricity Pricing, Cent. Energy Environ. Res. (2009) 1-30. doi:10.1017/CBO9781107415324.004. 
[154] European Commission, EU Buildings database, (n.d.). https://ec.europa.eu/energy/en/eu-buildings-databaseEU (accessed October 30, 2019).

[155] IEA, Energy Technology Perspectives 2017: Catalysing Energy Technology Transformations, 2017. doi:10.1787/energy_tech-2014-en.

[156] S. Luthra, S. Kumar, R. Kharb, M.F. Ansari, S.L. Shimmi, F. Ansari, S.L. Shimmi, Adoption of smart grid technologies: An analysis of interactions among barriers, Renew. Sustain. Energy Rev. 33 (2014) 554-565. doi:10.1016/j.rser.2014.02.030.

[157] National Grid, Balancing Services, (2018).

https://www.nationalgrid.com/uk/electricity/balancing-services/reserve-services.

[158] S. Blue, Institutional rhythms: Combining practice theory and rhythmanalysis to conceptualise processes of institutionalisation, Time Soc. 28 (2019) 922-950. doi: $10.1177 / 0961463 \times 17702165$.

[159] M.P. and G.O. Sustainability First (Judith Ward, What demand-side services can provide value to the electricity sector?, 2012.

http://www.sustainabilityfirst.org.uk/images/publications/gbelec/Sustainability First GB Electricity Demand - Paper 4 - What demand side services can provide value to the electricity sector -June 2012.pdf (accessed July 22, 2017). 